\title{
GPS 連続観測による日本列島上下地殻変動とその意義
}

\author{
国土地理院地理地殼活動研究センター* 村上 亮・小沢慎三郎
}

\section{Mapped Vertical Deformation Field of Japan Derived from Continuous GPS Measurements and Its Tectonic Implications}

\author{
Makoto Murakami and Shinzaburo Ozawa \\ Geography and Geodynamics Research Center, The Geographical Survey Institute, 1-Kitasato, \\ Tsukuba, Ibaraki 305-0811, Japan
}

(Received December 9, 2003; Accepted August 23, 2004)

\begin{abstract}
To evaluate a reliability of GPS vertical data we mapped vertical crustal deformation field of Japan using continuous GPS measurements with a nationwide dense network (GEONET) of the Geographical Survey Institute during the period from 1996 to 2003. We confirmed that the GPS vertical deformation field reasonably agrees with those derived from leveling, tidal record and geomorphologic analysis. The conformity with the other data sets suggests a dependability of the GPS vertical results. The GPS data illustrate details of a spatial pattern of the vertical deformation field and manifest their usefulness when applied to constrain tectonic models. A subsidence along the pacific coast of the southeastern Hokkaido propounds a possibility of a downdip extension of a plate coupling reaching to the depth of about $80 \mathrm{~km}$. Uplift around Hidaka mountains in the central Hokkaido suggests a present-day mountain building process at least during the interseismic period. An apparent subsidence found in the central mountainous region of the central Honshu island contrasts sharply with the presumed uplift through Quaternary inferred from geomorphologic analyses. Vertical deformations along the Nankai trough in the southwestern Japan can be attributed to an elastic deformation due to a dragging of the subducting Philippine Sea plate. The GPS result confirms a coupling of plates and a resultant strain accumulation in the Tokai region. Those results demonstrate the usefulness of the GPS vertical data and encourage us in further applications in the studies to understand ongoing tectonic processes in Japan.
\end{abstract}

Key words: Vertical crustal deformation, GPS, Tectonics, Mountain building, Plate coupling

\section{§1.はじめに}

わが国の精密測量の歴史は, すでに 100 年を大きく超 えている，上下地殼変動を知るために有用な水準測量は 1884 年に開始された. 約 70 年に及ぶ水準測量結果を集 大成した壇原 (1971)による成果は, 測地学的手法によ る日本の上下変動分布推定の一つの到達点として, 現在 でもテクトニクスに関する議論の重要な基礎となってい る.これまで，水準測量は，正確な上下変動分布を知る ためのほぼ唯一の手段であったが, 測量に人手と時間が かかること, また, 水準路線に沿った線的な情報しか得 られないことが大きな制約であった。

1980 年代の後半になって本格的に登場した GPS は

* $\mathbf{7} 305-0811$ つくば市北郷 1 番
目覚ましい成功を収め, わが国では, 1990 年代に入る 頃から固定点による観測が開始された．GPS は面的な 展開が可能で, 連続観測も行えることから, 地壳変動の 詳細な空間分布とその時間変化を明らかにするための新 たな可能性を開いた。国土地理院は，1994 年に東海・ 南関東地方に抢いて連続観測を開始し，その後も観測網 の拡張を行って, 2004 年 4 月現在, 観測点数は 1,200 点に達している. 点数抢よび空間密度において世界の先 端をいくこの連続観測により, テクトニクス, 地震メカ ニズム, 火山噴火メカニズムについての理解を深める 様々な成果が上がっている。 しかし，それらの解析は， 水平変動成分のみに立脚している場合が多く, 精度が劣 るとされる上下成分は棄却され，省みられることが少な かった. 
GPS は本来 3 次元的な測位手法であり，モデルの構 築に上下地殼変動が重要な役割を果たす場合も多いこと を考えると，上下変動を積極的に利用する努力が払われ るべきである．特に，均等かつ高い空間密度で観測が続 けられているわが国においては, GPS 上下変動を考慮 することによって，テクトニクスの議論に新しい展開が もたらされる期待がある. GPS の測位解析方法は観測 開始当初より著しく改善されており，7 年を超えるデー 夕の蓄積が進んだこともあって，GPS 上下変動の精度 が総合的に向上し，利用の条件が整いつつある.

以上のような考えに基づき，国土地理院の GPS 連続 観測結果を用いて, 上下変動速度を解析した. その結果, GPS 上下変動は, 十分な信頼性があると判断され，それ を積極的に利用することにより，日本周辺のテクトニク スの新たな理解につながる期待があることがわかった。 本論文では, GPS の上下変動の信頼度を評価し, そこか ら得られる上下変動分布とその意義について議論する. 同様の研究として, Aoki and Scholz (2003) があるが, 我々は, GPS と水準測量結果などとの詳細な比較を試 みるほか, 地学的な議論についても, 彼らとは異なった 観点加ら考察を加える.

\section{§2. GPS による上下変動観測}

精密測位手法としての GPS は, 1980 年代の後半頃か らわが国に導入された．国土地理院も各種の試験観測を 行ってその有効性を認識し, 1994 年の春加ら, 東海・ 南関東地域において 110 点の連続観測点網の運用を開 始した. GEONET (GPS Earth Observation NETwork) と名づけられたこの観測網 [Hatanaka et al. (2003)] の 総点数は, 何度かの拡張を経て 2004 年 4 月の時点で 1,200 点となっている. 観測網の構築が段階的に進んだ ため, 主として 3 種類の受信機から構成されることとな り，これらが並行して用いられてきた．最近になって， 受信機の機種およびアンテナが同一のものに順次更新さ れ, 2004 年 4 月以降は, 極めて少数の例外を除き, 単一 機種の受信機およびアンテナが使用されている. GEONET の解析には, 測位解析ソフトウェアとして Bernese/BPE [Hugentobler et al. (2001)] が用いられ， つくば市の国土地理院構内にある観測点を基準局とした ITRF 座標系 [Ferland (2000)] に基づく各観測点の位置 が， 24 時間分のデータを利用して毎日計算されている [Hatanaka et al. (2003)].

GPS による上下方向の測位は, 観測の原理上, 水平方 向に比較して不利な条件を抱えている. GPS 測位にお いては, 視界の開けた上方に存在する衛星を位置の基準 として用いており, 観測点から見た衛星の幾何学的配置
は，上下に関しては対称ではない，その結果，上下方向 の観測誤差が，水平方向の誤差より大きくなるという根 本的な弱点がある. また，多くの場合，測定対象とする 地壳変動のシグナル自体, 水平に比べて小さく, そのこ とも, 上下地殼変動検出を一層困難なものとしている. このため, 従来の GPS を利用した地殻変動やテクトニ クスの解析においては, 上下成分の信頼度は低いとさ れ, 多くの場合, 水平変動のみが利用されてきた.

しかし，最近では，状況が変わりつつある．国土地理 院の GPS 連続観測も，全国における本格的な観測が開 始されて以来, ほほ 7 年以上が経過し, デー夕そのもの の蓄積に加えて, 経験の蓄積による処理技術の向上がも たらされている，従来のものに改良を加え，この観測網 に最適化した最新の測位解析手法が採用されており, 1996 年 4 月以降のデータが同一の手法で計算処理され ている [Hatanaka et al. (2003)]. その結果, それ以前の 解析方法に残存していた系統誤差が解消されたほか, 日々の測位解のばらつきも減少して, 測定の信頼性が大 幅に向上した。このような改良の結果, GEONET の成 果は上下成分についても地球科学的な議論に十分耐える レベルに達していると期待される．本稿では，1996 年 以降の GPS 連続観測結果の時系列への直線近似から上 下変動速度を求め, テクトニクスの立場から検討する.

\section{§3. GPS によるわが国の上下変動速度分布 3.1 使用する GPS データ}

わが国において現在進行している上下変動を明らかに するため, GEONETによる 1996 年から 2003 年まで の日々の測位解を用いて平均的な変動速度を計算し, そ の分布を求める. 使用するデー夕は, 複数機種が並行し て用いられていた期間を含んでいる。この間は, 同一の 受信機タイプの観測点で構成するサブネットが機種ごと に構築され，個別の測位計算がなされている。サブネッ 卜間では参照点が異なり，アンテナ保持機構の筐体や地 盤に固定する基台の構造についても同一でない場合があ り，系統誤差が存在する恐れがある，異機種のデー夕を 一括して使用するためには，相互の系統差がないことを 確認する必要がある.

このため, 異機種観測点のうち距離の近いものを組み 合わせ, 上下変動速度の差の有無を調べた. サンプルは, 全国に分布するおよそ 100 対のペアであり, 異機種隣接 点間相互の距離は $25 \mathrm{~km}$ より短い，場所の違いによる 差は, 小さいと考えられ, 変動速度に差が現れる場合は, 機種の相違による系統差である可能性が高い. 実際に計 算してみると,これらの観測点間の変動速度の差の平均 值は $0.3 \mathrm{~mm} /$ year, 標準偏差は $2.5 \mathrm{~mm} /$ year であっ 
た．わが国の上下変動速度は, 概ね $+/-10 \mathrm{~mm} /$ year の範囲に分布するので, 機種による差は, 地壳変動に比 べて十分小さいと判断できる.

この結果を踏まえて, 異機種のデータを一括して活用 することとし，全体で約 950 点のデー夕を採用した。こ れにより, GEONET の特徴である空間分布の一様さと 密度の高さのメリットを最大限に利用することができ る.

観測期間は，機器が設置された時期により異なるが, 地震等の影響を取除くために対象期間を短縮した少数の 例外を除き, 最長で 1996 年 4 月から 2003 年 4 月まで の 7 年間, 最短で 1998 年 4 月から 2003 年 4 月の 5 年 間である。

\section{2 デー夕解析手法}

GPSによる精密測位は, 観測点間の相対位置を高精 度に決定する相対測位であり, 国土地理院の測位計算 [Hatanaka et al. (2003)] も，この原理に基づいている. したがって, 上下変動を計算するためには参照点を選定 する必要があるが, 本論文では, 試行錯誤的にいくつか の候補を調査し, 最終的に, 観測の欠落が少なく, 周囲 の樹木による電波遮蔽や地下水などの影響による不安定 性が見られない日本海の飛島（山形県, GEONET の ID 番号：950194）を選んだ.ただし, 解析を進める過程で, 飛島が継続的に隆起している可能性が明らかになったた め (3.3 節参照), 第一段階として飛島に対する各点の変 動速度を求め, 最終的には, 全体をシフトさせて全国の
上下変動の平均が 0 になるように基準を取り直して，各 種の議論を行うことにした。

GPS 観測点には，地すべりなど局所的な要因によっ てテクトニックな地殸活動と直接関係のない変動が生じ ているあのあある。，それらを排除するため，周囲の上下 変動の傾向と大きく異なる観測点を抽出し, ある 1 点の みが周囲と異なる動きをしている場合は, 異常と判断し てデータから除外した．しかし， 2 点以上の点が同様の 傾向を示す場合は，たとえそれが周囲の大局的なトレン ドと異なっていても有意なデータとして採用した。この 選別の過程で約 50 点を除外し, 最終的に残った約 950 点の GPS 点の上下变動速度を議論する.なお,このスク リーニングの過程でも, 受信機機種の相違する近接点間 の上下変動值に大きな食い違いが現れることはなく, 異 機種のデータを統一して扱ってもよいことが再確認され た.

本論文では, 継続して進行する上下変動に注目するこ ととし, 地震によるステップ状の地款変動が見られる観 測点については, 対象期間から地震の影響を含む期間を 除外して変動速度老計算した。1997 年豊後水道ゆっく り地震, 2000 年鳥取県西部地震, 2001 年芸予地震など が除去の対象である．この間にいくつかの火山活動も発 生している. 1998 年岩手山の活動抢よび 2000 年有珠 山噴火に関連する地殻変動については, 火山活動特有の 複雑な変動が長期間にわたり，それらを除去したデー夕 は直線近似の対象期間としては短くなりすぎるため, 観

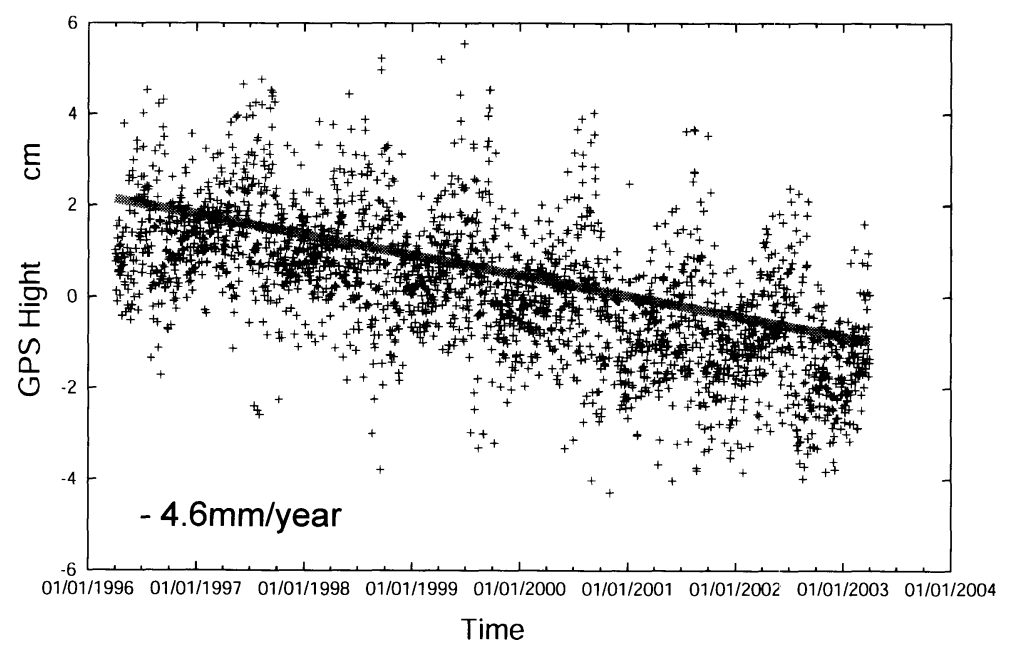

Fig. 1. Time series plots of ellipsoidal height at a GEONET (GPS Earth Observation Network) site (Kochitano: 950444) near the cape Muroto in Shikoku as referred to a fixed site in the northeastern Japan (Tobishima: 950194) during April 1, 1996 to April 1, 2003. The r.m.s. of daily solutions is about $12 \mathrm{~mm}$. The vertical velocity is $-4.6 \mathrm{~mm} /$ year with a formal error of about $+/-0.1 \mathrm{~mm} /$ year. The subsidence is caused by an elastic deformation of the continental plate dragged by the subsiding Philippine Sea Plate. Repeated precise levering surveys confirm this subsidence. 
測点そのものを解析の対象から外した. しかし, 群発地 震が繰り返し発生する伊豆半島東部の地款変動, および 2000 年以降続いている東海地方の地殼変動 [Ozawa et al. (2002)] は, 一定の傾向の変動が長期間継続している ことから，その期間を除去せず，継続的な上下変動とし て変動速度を計算している。

飛島に対する高さの変化の一例として室戸岬近傍の GEONET 点「高知田野」(950444) の時系列を Fig. 1 に 示す.この点は, 室戸岬に近く, フィリピン海プレート の沈み込みの影響を受けて沈降していることが, 最近の
水準測量でも確認されている．日々の観測值はばらつい ているが，飛島に対する長期的な沈降を示す直線的な傾 向を明瞭に読み取ることができる. 直線近似による変動 速度は, $-4.6 \mathrm{~mm} /$ year, 残差の標準偏差は $12 \mathrm{~mm}$ で ある. 他の観測点の時系列も基本的に類似の様相をして いる．観測値のばらつきに相当する残差の標準偏差は, 固定点からの距離や，アンテナ周囲の電波遮蔽状況な ぞ, 観測点固有の条件によって左右される.したがって, 標準偏差の大きさも観測点によって異なるものの，概ね 10〜20 mm 程度である.この値から, 7 年分のデータを
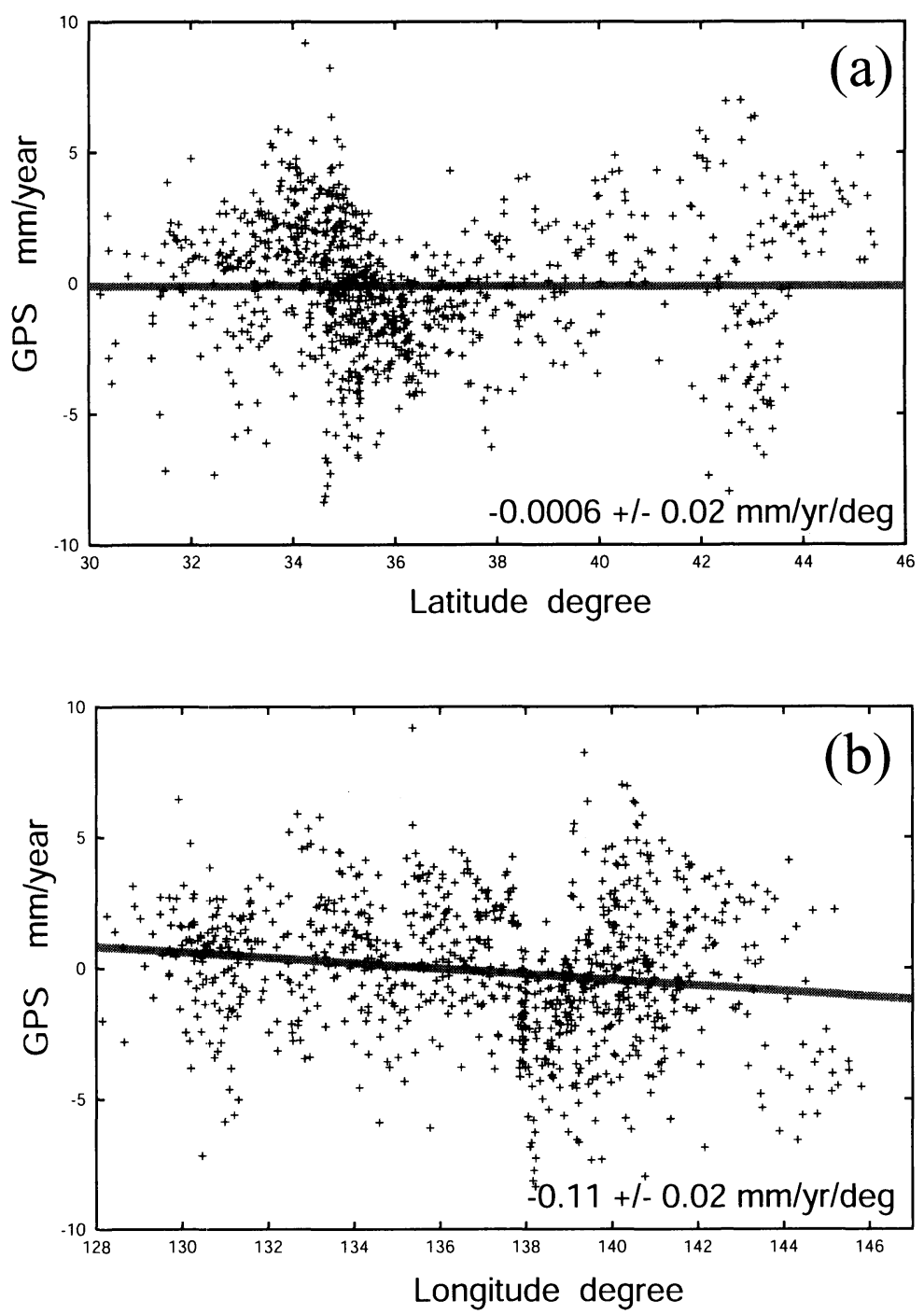

Fig. 2. Correlation plots between the GPS vertical velocity and (a) latitude and (b) longitude of each GPS site. Correlation between velocity and coordinates is an indicator of systematic error involved in positioning computation of the GPS. Dependency on latitude and longitude is reasonably small suggesting that no significant systematic error is involved in the positioning computation. 
用いた一次傾斜の推定誤差を計算すると, $0.1 \sim 0.2$ $\mathrm{mm} /$ year 程度となる. 実際の变動は直線的ではなく, また䛊差も完全にランダムではないため，直線近似によ る誤差の推定值は, 上下変動速度の誤差の見積もりとし ては, 楽観的過ぎる.しかし, 仮に, 誤差をこの 10 倍と 見積もった場合でも，推定誤差は 1〜2 mm/year 程度 となり，わが国で見られる通常 $+/-10 \mathrm{~mm} /$ year の範 囲の上下変動に対しては十分小さい. GPSによる 7 年間 の連続観測結果を平均した上下変動速度の精度は, 解析 手法の改良およびデータの蓄積を経て，テクトニクスを 論じるために必要なレベルに達していると判断できる.

測位解の系統誤差についても検討する，系統誤差は多 くの場合, 観測点間の距離に比例することが知られてい る. そのような䛊差の一例として, 日々の測位計算 [Hatanaka et al. (2003)] に拈いて, 固定点として扱うつ
くば基準局の ITRF 座標 [Ferland (2000)]における仮 定位置の誤りがもたらす誤差がある。この基準局は，プ レート運動によって数 $\mathrm{cm} /$ year の速度で ITRF 座標系 の中で移動しているが，GPS 測位解析計算の過程で，こ の移動速度を無視すると，系統的な位置誤差が生じる. 誤差は, 緯度や経度への依存性をむつことが予想される ため, その有無により測位計算の妥当性を判定すること ができる．初期の GEONET の解析計算では，つくば基 準点の移動が無視されていたため, 日々の測位解に明ら かな座標依存性が見られた. 最新の統一解についてはこ の問題は解決されているが, 確認の意味で, 全点の上下 変動の座標依存性を検討した. Fig. 2 にその結果を示す ように，緯度への依存性は， $-0.0006+/-0.02 \mathrm{~mm}$. $\mathrm{yr}^{-1} \cdot \mathrm{deg}^{-1}$, また経度への依存性は, $-0.11+/-0.02$ $\mathrm{mm} \cdot \mathrm{yr}^{-1} \cdot \mathrm{deg}^{-1}$ であり，いずれあ小さく，緯度や経度

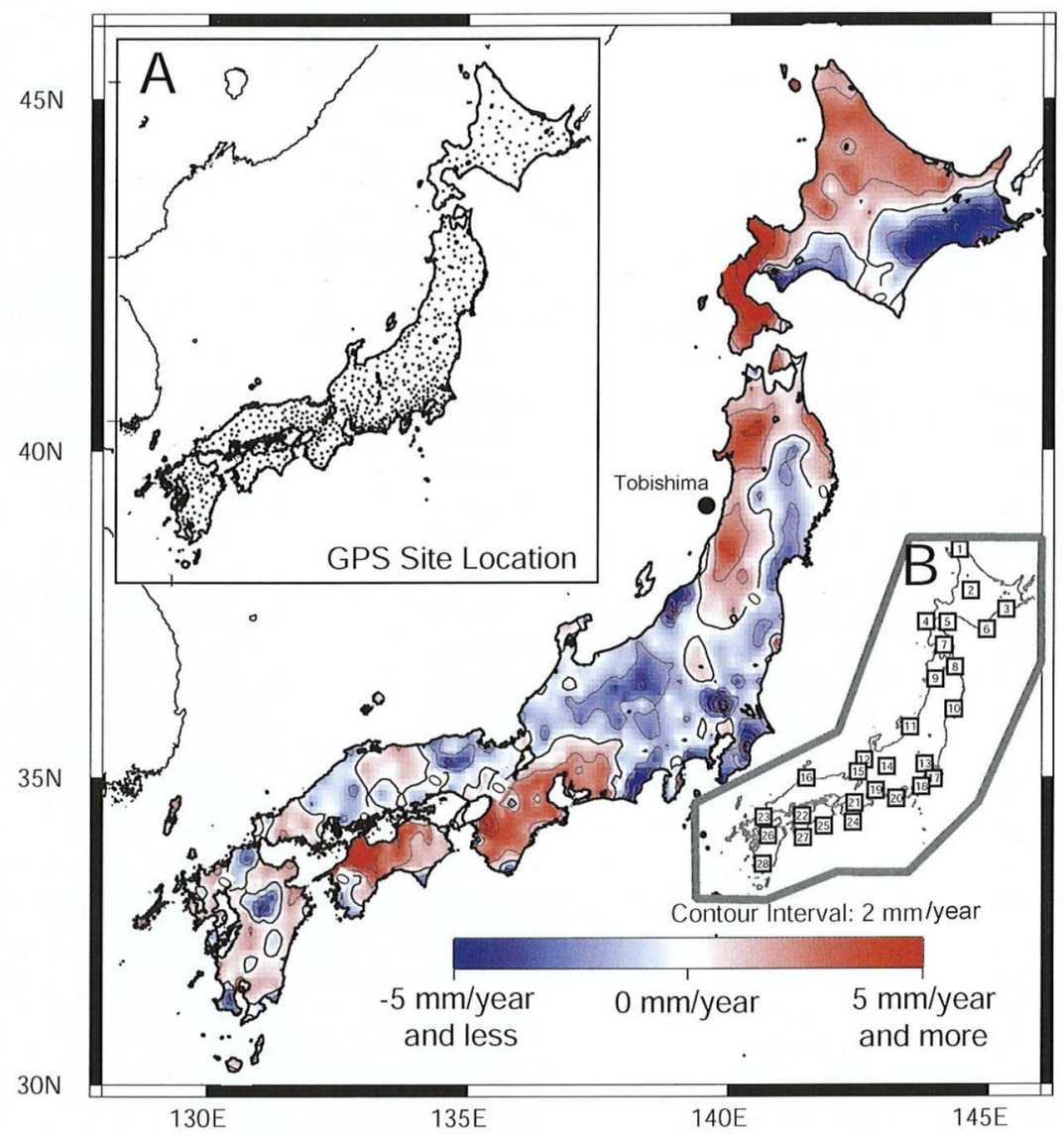

Fig. 3. Vertical velocity field in Japan mapped from GEONET data during the period of 1996-2003. The vertical velocities refer to a fiducial reference station in such that the average of vertical velocities of all the stations equals to zero. The red color means uplift, whereas blue indicates subsidence. The spatial pattern of deformation field strongly suggests its relationship to the tectonic setting of Japan. Inset map A shows site locations of about 950 stations used in this figure. Inset map B depicts the locations of the stations listed in Table 1. 
との明瞭な関連性は認められなかった。

また, 最近の研究は, つくばの基準局が, 周辺の地下 水の汲み上げを原因として年周的な上下変動を繰り返し ていることを明らかにしている[Munekane et al. (2004)]. これにより GPS 点間の距離に比例する誤差が 混入しうるが，この䛊差は周期的であり，少なくとも 5 年以上の期間の平均的な速度を用いる本論文の解析には 影響がない.

なお, 高さの定義についても述べておく，GPS 観測で 得られる高さは楕円体を基準面とする棈円体高である. それに対し，水準測量や験潮観測で求まる高さは, ジオ イドや海面を基準面としており，厳密にはそれぞれに基 準が異なる。しかし，今回は，上下変動速度を議論の対 象としており, 基準の違いによる差は無視することがで きる. したがって, 本論文の議論では GPS, 水準测量お よび験潮結果による変動速度を直接比較する.

\subsection{GPS による上下変動分布}

3.2 節に説明した手順で, 固定点である飛島に対する
各点の相対的な上下変動速度を計算したところ, 約 $78 \%$ GPS 点が沈降していることがわかった. 平均お よび中央值は, いずれも-3.3 mm/year である.このこ とは, 参照点とした飛島の隆起を強く示唆している. 6.4 節において検討するように，東北地方の日本海側は大き く隆起しているので, この隆起が日本海の沖合いの飛島 まで及んでいると考えても不自然ではない. 飛島の隆起 の影響を受けて, 全国の上下変動速度が沈降側にシフト している可能性が高いため, 全国の平均値が 0 となるよ うに基準を取り直すことにする．新しい基準で表示した 上下変動分布を Fig. 3 に示す. Fig. 3 の上下変動速度 は, 全体が, +/-10 mm/year の範囲にほぼ収まって おり， $90 \%$ 以上が+/ $-5 \mathrm{~mm} /$ year の範囲に分布する. 過去の水準測量から導かれた上下変動速度 [壇原 (1971)] の大きさも同程度であり, GPS 結果はこれと符 合する.

Fig. 3 の上下変動分布は, ランダムではなく, 隆起お よび沈降の配置に一定の規則性が見られる，また，分布

Table 1. GPS vertical velocities at picked-up GEONET sites. The locations of the sites are indicated in the inset map B of Fig. 3. The vertical reference frame is the same as Fig. 3. Most of vertical velocities are within $+/-10 \mathrm{~mm}$ /year renge. A positive sign means uplift.

\begin{tabular}{|c|c|c|c|c|c|}
\hline No. & GEONET ID & GEONET Site Name & Longitude (deg) & Latitude (deg) & Velocity (mm/year) \\
\hline 1 & 940001 & Wakkanai & 141.7543 & 45.4008 & 1.7 \\
\hline 2 & 960508 & Asahikawa & 142.4134 & 43.7361 & 3.4 \\
\hline 3 & 940010 & Kushiroshi & 144.4359 & 42.9607 & -5.4 \\
\hline 4 & 940017 & Setana & 139.8612 & 42.4483 & 4.8 \\
\hline 5 & 970792 & Noboribetsu & 141.0847 & 42.418 & -3.4 \\
\hline 6 & 960532 & Erimo 2 & 143.3195 & 42.123 & 1.1 \\
\hline 7 & 950150 & Sai & 140.8841 & 41.4527 & 2.8 \\
\hline 8 & 950156 & Hachinohe & 141.5149 & 40.5126 & 3.7 \\
\hline 9 & 950185 & Ani & 140.4054 & 40.0041 & 3.6 \\
\hline 10 & 950175 & Shizugawa & 141.4529 & 38.6798 & -1.0 \\
\hline 11 & 940050 & Niigata & 138.9921 & 37.8935 & -6.0 \\
\hline 12 & 950255 & Komatsu & 136.3919 & 36.3914 & 1.2 \\
\hline 13 & 93003 & Sanwa & 139.8138 & 36.2005 & -11.5 \\
\hline 14 & 960611 & Nagawa & 137.6857 & 36.0815 & -2.5 \\
\hline 15 & 960580 & Kouno & 136.0589 & 35.8337 & -1.0 \\
\hline 16 & 960656 & Mihogaseki & 133.1405 & 35.5604 & -1.2 \\
\hline 17 & 93027 & Oamishirosato & 140.3215 & 35.5268 & -12.7 \\
\hline 18 & 960759 & Miura 2 & 139.617 & 35.1576 & -5.6 \\
\hline 19 & 950302 & Chiryu & 137.0627 & 34.9917 & 3.1 \\
\hline 20 & 93101 & Omaezaki & 138.2187 & 34.602 & -8.1 \\
\hline 21 & 940068 & Narayoshino & 135.8542 & 34.389 & 4.1 \\
\hline 22 & 950433 & Ehimekawauchi & 132.9142 & 33.7932 & 4.9 \\
\hline 23 & 960685 & Nogata & 130.7519 & 33.7422 & -3.1 \\
\hline 24 & 940070 & Kushimoto & 135.7672 & 33.48 & -5.8 \\
\hline 25 & 940082 & Muroto & 134.1248 & 33.3125 & -4.3 \\
\hline 26 & 960701 & Choyo & 130.9986 & 32.8674 & -5.6 \\
\hline 27 & 940085 & Tosashimizu & 132.9689 & 32.7523 & -3.1 \\
\hline 28 & 960722 & Tarumi & 130.7017 & 31.4927 & 1.8 \\
\hline
\end{tabular}


の様相が東北日本と西南日本とで大きく異なっているこ とも興味深い. 沈降と隆起の境界線が火山フロント近く の内陸部まで後退している東北日本とは対照的に, 西南 日本の南海トラフ沿いの地域では, トラフに面した四国 東部や紀伊半島が海岸線近くから直ちに隆起しており, 両者におけるテクトニックな状況の差異を暗示してい る. 一方, 中国地方や九州地方は局所的な隆起や沈降は あるものの, 全体を支配する大きな規則性のあるパター ンは認められない.

各地の上下変動の大きさを見るため, 各地域を代表す る GPS 点を選び, 上下変動速度を Table 1 に示す. 各 点の位置はFig. 3 の挿入地図 B に表示する. ほとんど の点において, 上下変動速度は+/-10 mm/year の範 囲に入っている. 観測点の中には, No. 13 三和, No. 17 大網白里など $10 \mathrm{~mm} /$ year を超える沈降を示している 点ああるが，これらは地下水の汲み上げなどによる地盤 沈下を反映している.

北から地域ごとに, 簡単に上下変動の特徵を述べる. No. 1 「稚内」, No. 2 「旭川」が代表する北海道北部から 中部にかけての領域は隆起が支配的である. 一方, No. 3 「釧路市」に示されるように, 北海道東部の太平洋側は大 きく沈降している. また, 北海道西部の太平洋側の No. 5 「登別」周辺も沈降している. しかし日高山脈に近い No. $6 「 え り も 2 」 に$ 見られるように, 襟裳岬周辺の点は 隆起を示している. この隆起は日高山脈の形成との関連 が示唆され， 6.1 節でより詳細に議論する. 渡島半島の 日本海側にある No. 4 「瀬棚」周辺は顕著に隆起してい るが， 6.3 節で検討するように, 1993 年北海道南西沖地 震後の余効変動である可能性が高い.

東北地方では, No. 9 「阿仁」, No. 7 「佐井」, No. 10 「志津川」に代表されるように, 日本海側が隆起し, 太平 洋側が沈降している. しかし，No.8「八戸」など太平洋 側であ隆起している場所もある。これらは 1994 年三陸 はるか沖地震の震源域に近く, この地震の余効変動との 関連が示唆される (6.4 節).

No. 11 新潟」では, 地盤沈下が続いているが, そこ から西の日本海側は, No. 12 「松」, No. 15 「河野」, No. 16 「美保関」に代表されるように，比較的安定して いる. No. 14 「奈川」は中部山岳地帯に位置するが, 同 山岳地帯は沈降が支配的である.

No. 18 「三浦 2 」, No. 20 「御前崎」, No. 24 「串本」, および No. 25 「室戸」が沈降している. また, No. 19 「知 立」, No. 21 「奈良吉野」, および No. 22 「愛媛川内」が 隆起しているが, これらは, フィリピン海プレートの沈 み込みに伴う変動と解釈できる (6.6 節参照). 一方, No. 27 「佐清水」が代表するように, 四国の南西部は沈降
している.

九州地方や中国地方は, 空間波長の短い隆起・沈降の 分布はあるものの, 全体を支配する大きな規則的なパ ターンはない. 九州北部の No. 23 「直方」の沈降は, 過 去の採炭活動と関連している可能性が高い. また，九州 中央部の No. 26 「長陽」は, 阿蘇カルデラ内に位置して おり, 同カルデラ内の他の 2 点とともに系統的に沈降し ている. また, 隣接の九重山近傍にある観測点も沈降し ている.これらの沈降は, 阿蘇カルデラおよび九重山の 火山活動に関連する变動である可能性が高い (6.8 節).

以上，概略を見たように，Fig. 3 の隆起や沈降の分布 には, 地域ごとに系統性が見られ, 東北日本と西南日本 の大きな傾向の違いがあることや, 隆起や沈降の境界が 海溝軸と平行に走ることなど, 日本列島周辺のテクトニ クスの空間的な特徵との類似性が高く, 地球科学的に極 めて重要な情報であることを予想させる.

\section{§4. 水準測量による上下変動との比較}

\section{1 水準測量による最近 40 年間の上下変動}

わが国では，これまでに，全国を一周する計 8 回の水 準測量が実施されている [国見・他 (2001)]. 本論文で は, 3 回目（1947 1961 年）と 8 回目（1986 1999 年) の測量結果の相互比較加ら, 最近約 40 年間の日本 列島の上下変動速度分布を求め, GPS 結果と比較する.

観測点の移設に伴う見かけの変動などの異常データを 除外すると, 全国約 4,900 点の水準点が解析対象として 残った. 真の地款変動を反映していると考えられるこれ らのデータについて, 東京の水準原点を仮不動点とする 上下変動量を計算した. ただし, 全国測量において,す べての一等水準路線が計測されるわけではないので, 北 海道北部・南部や三陸沿岸など，ここで使用した測量が カバーしていない地域もある. 最近の 40 年間に, 最も 大きな隆起を示した場所は, 紀伊半島南端の潮の岬周辺 で, 隆起量は約 $0.6 \mathrm{~m}$, 最大の沈降は新潟市周辺で, 沈降 量は約 $2 \mathrm{~m}$ である. このデータをもとに, 水準点ごとに 観測の時間間隔を考慮し, 平均的な上下変動速度を計算 した.

水準測量の誤差を見積もることは容易ではない，統計 的には誤差は観測距離の平方根に比例するとされてお り, 距離が延びるに従い, 誤差が累積していく傾向があ る. 国土地理院の一等水準測量のマニュアルは, 観測の チェックのため, 同じ路線を往復測定することを規定し ている [国土地理院 (2001)]. S (km) の距離を観測して 往復で $2.5 \mathrm{~mm} \times \sqrt{\mathrm{S}}$ を超える誤差が発生した場合には, 測量をやり直すことになっている．この式が誤差の見積 ありに使われることが多い. 測量は東京の水準原点から 
出発しており，北海道および九州までの距離は約 1,000 $\mathrm{km}$ である.この式により䛊差を計算すると，路線の両 端において累積誤差はおおよそ $7.9 \mathrm{~cm}$ 程度となる。さ らに現実性を高めて, 網平均を考慮して水準測量の䛊差 を解析した井内 (1974)による見積りも, 最大で $6 \mathrm{~cm}$ と，ほぼ同程度の大きさである，2 回の水準測量の差か ら変動速度を計算するので, 1 回分の水準測量の誤差を $\sqrt{2}$ 倍し，それを期間の 40 年で割ると, 速度の推定誤差 は約 $2.8 \mathrm{~mm} /$ year となる. 概略の見積もりであるが, 一つの目安として，これを超える変動は有意とみなすこ とができる．また，空間波長が短い変動についてはその 検知に必要な測量の路線長が短くなるので, 誤差はより 小さくなることが期待される. わが国の上下変動は，お よそ+/-10 mm/year の範囲に分布するため, 水準測 量は，これらを検出するのに十分な精度を有していると
判断できる.

対象とした期間中に，水準測量結果に影響を与えうる 地震がいくつ屯発生している. 海域では $M 7.0$ 以上の地 震について，また陸域では $M 6.5$ 以上の地震について， その影響をモデル計算により除去することとした。 1987 年までの地震については, 「日本の地震断層パラ メータ・ハンドブック」[佐藤・他 (1989)] に記載され たパラメータを用い, それ以降の地震は, 地震予知連絡 会報などに公表されたモデルを用いて上下変動を計算 し，水準測量結果に補正として加えて影響を除去した。 考慮した主な地震は, 1964 年新潟地震, 1993 年北海道 南西沖地震, 1994 北海道東方沖地震, 1994 三陸はるか 沖地震などである。なお，火山噴火については補正して いない.

このようにして計算した全国の水準点の变動速度の平

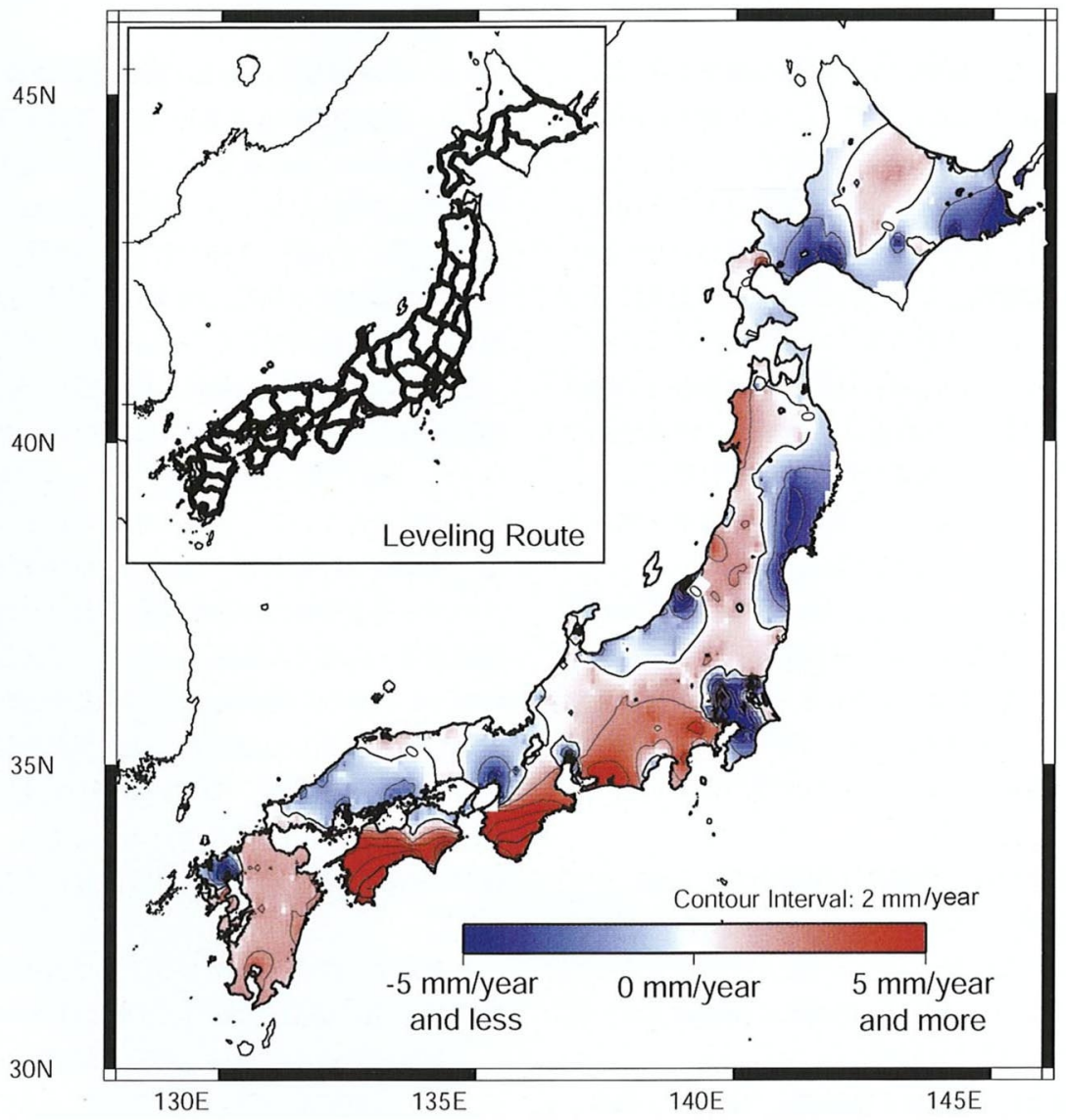

Fig. 4. Vertical velocity field in Japan mapped from repeated leveling surveys. The height changes were derived from surveys between 1947-1961 and 1986-1999 carried out by the Geographical Survey Institute. The vertical velocities refer to a fiducial reference in such that the average of vertical velocities of all the stations equals to zero. There is an alikeness of the spatial pattern of deformations between this figure and Fig. 3. Inset map shows site locations of about 4,900 leveling bench marks used in this figure. 
均および中央值はともに-2.8 mm/yearで, 全体の約 $86 \%$ が沈降を示し, 変動の分布は沈降側に偏倚してい る.この結果は, 3.3 節の GPS の場合と同様に, 参照点 である東京の水準原点の隆起の可能性を示唆している. 水準原点付近は, 1923 年関東地震の際の地震時変動之 して約 $8.6 \mathrm{~cm}$ 沈降したが，その後プレート境界のカッ プリングが回復して上盤プレートが変形する結果, 関東 地震時の変動とは逆向きに, ゆっくりと隆起している可 能性がある.

関東地震の震源断層領域が現在は固着していると仮定 し，そのバックスリップの量を $25 \mathrm{~mm} /$ year として, 関 東地震の代表的なモデル [Ando (1974)] に基づいて水準 原点付近の上下変動を計算すると, 約 $1.5 \mathrm{~mm} /$ year の
隆起となり，この程度の変動が生じていても不思議では ない. また, 水準原点と三浦半島油蔷験潮場の間では, 最近の 30 年間, 水準測量が毎年繰り返されているが, その結果は, 油盇に比べて水準原点が約 $4.2 \mathrm{~mm} /$ year の速度で隆起したことを示している[国土地理院 (2002)]. 一方, 加藤・津村 (1979) の方法により解析し た験潮結果は, 油壳験潮場が $3.4 \mathrm{~mm} /$ year の速度で沈 降したことを示す [国土地理院 (2003a)].この二つの結 果は, 水準原点が約 $0.8 \mathrm{~mm} /$ year の速度で平均海水面 に比べて隆起していることを意味しており，これからも 水準原点の隆起の可能性が指摘できる.

さらに, GPS の上下変動からも同様の示唆が得られ る. Fig. 3 に用いた GPS デー夕は, 水準原点付近が約 1

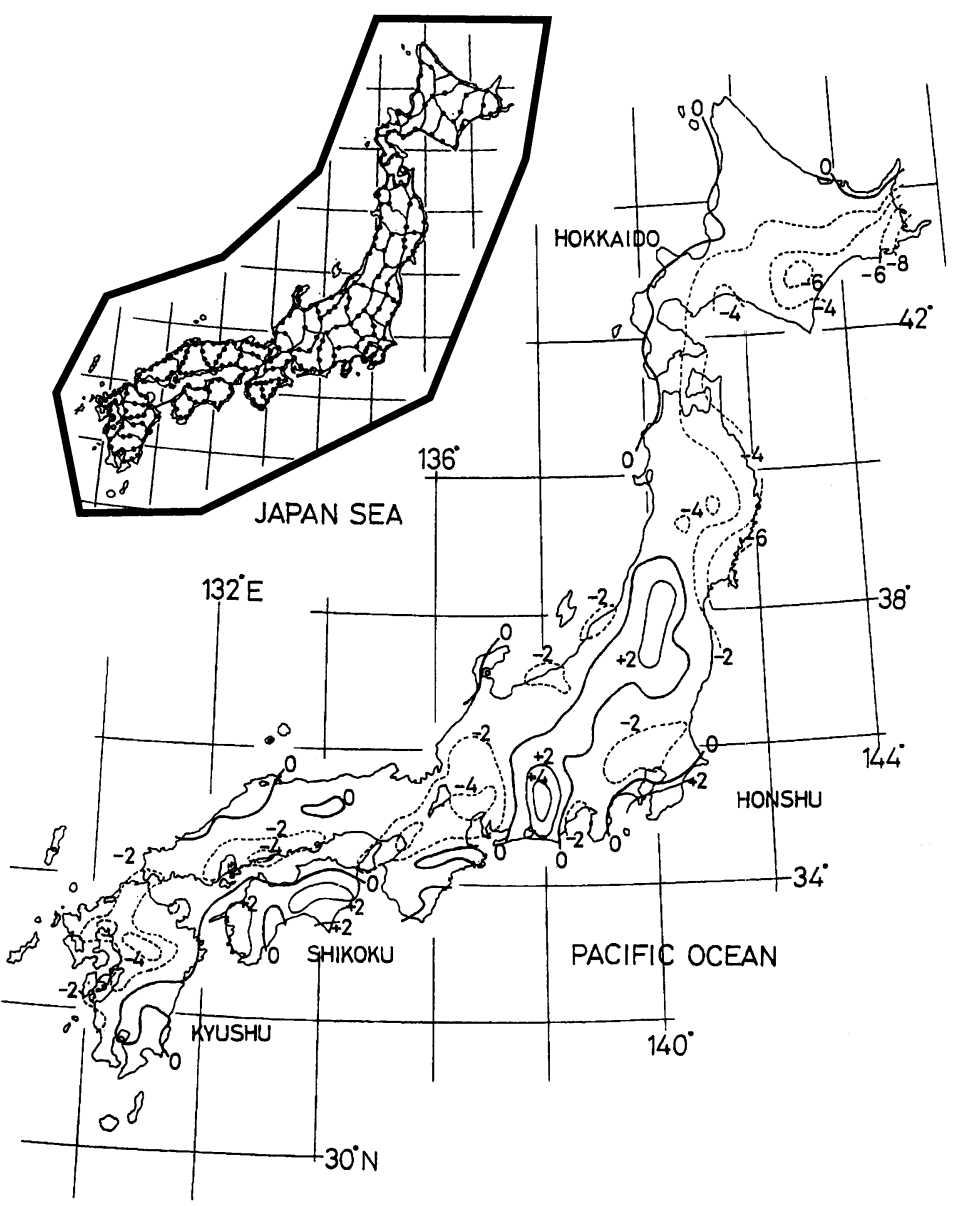

after Danbara(1971)

Fig. 5. Vertical velocity field in Japan mapped by Danbara (1971) from repeated leveling surveys carried out in around 1895, around 1930, around 1950, and around 1965 by the Geographical Survey Institute and its predecessor organization. The vertical velocities refer to the vertical datum of Japan located in Tokyo. Inset map shows leveling routes used in the figure. 
$\mathrm{mm} /$ year 程度の速度で隆起していることを示してい る.

結論として，水準測量による上下変動の全国平均を 0 にするために要請された $2.8 \mathrm{~mm} /$ year の $1 / 3$ から半分 程度が, 水準原点の隆起で説明できる。なお, 過去の地 盤沈下屯水準測量の平均值を沈降側にシフトさせる要因 として働いている. 水準測量の対象期間の前半である 50 年代から 60 年代にかけては, 全国的に都市部で地盤 沈下が顕著であり,これも全体の平均値を引き下げる効 果がある. 以上の要因が複合的に作用して, 平均值が沈 降側にシフトした可能性が高い.

GPS との比較を容易にするため, 水準測量結果につ いても, 全点の平均が 0 となるように基準を取り直し, 空間的なフィルタリング処理を経て上下変動の面的分布 を表示した図が Fig. 4 である.

Fig. 4 で大きな沈降を示している地域は，その多くが 新潟市周辺や関東地方北部などの地盤沈下地帯である. その一方で, 北海道の太平洋側, 東北日本の太平洋側な ど, 広い領域が系統的に沈降している場所がある.また, 系統的に隆起している地域むあり, 東北地方の日本海 側, 東海地方から, 紀伊半島, 四国地方にかけての太平 洋に面した帯状の領域などがそれにあたる.これらの広 域的な隆起や沈降は, 日本列島のテクトニクスを反映し た重要なシグナルである可能性が高い.
なお，Fig. 4 の分布は路線上に分布するデー夕に空間 的なフィル夕処理を施した結果である. 内挿・外挿の信 頼性を考慮して $60 \mathrm{~km}$ 以内に水準点が存在しない地域 は着色していない, 北海道の南北の両端, 東北の三陸海 岸などが着色除外地域である。 また, 図では伊豆半島も 着色されているが，実際には水準デー夕はない，このよ うに, 路線からの距離によって結果の信頼度が異なるの で, 図の解釈には注意が必要である。

\subsection{GPS 結果と水準測量結果の比較}

GPS による最近 7 年間の上下変動である Fig. 3 と, 水準測量による過去約 40 年間の上下変動分布である Fig. 4 とを比較する. 一見して, 両者の空間パターンに 強い類似性のあることがわかる. 北から順に見ていく と, 根釧台地から十勝平野周辺抢よび勇払平野周辺の沈 降, 仙台市付近の沈降, 東北地方の日本海側の隆起, 関 東平野北部抢よび房総半島周辺の沈降, 紀伊半島および 四国の内陸部の隆起など, 多くの地域で GPS および水 準測量結果による隆起・沈降のパ夕ーンの共通性か認め られる。

1960 年代以前の約 70 年間の水準測量結果を用いた 壇原 (1971) による成果とも比較する. 彼は, 過去の 4 回 の水準測量, すなわち, 1895 年前後, 1930 年前後, 1950 年前後, および 1965 年前後に実施された水準測 量結果を使用して Fig. 5 に示される上下变動速度分布

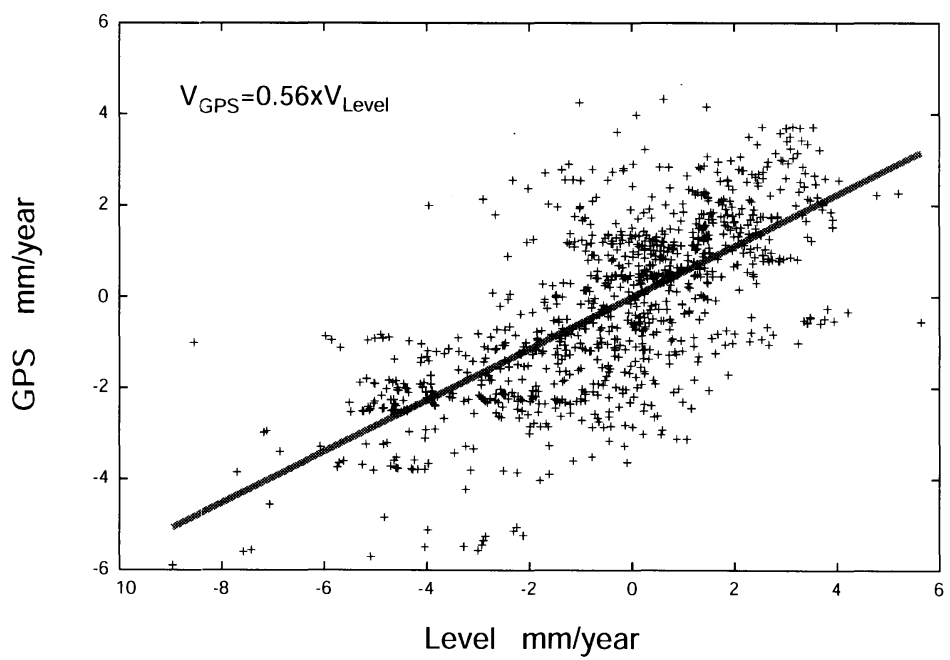

Fig. 6. Correlation plots between vertical velocities by leveling and GPS in the Tohoku region whose latitude is between 37 and 40.5 degrees. The velocities by leveling are derived from repeated surveys carried out between 1947-1961 and 1986-1999. The GPS velocities are derived from continuous measurements during 1996-2003. Unit of the velocity is in mm/year. The GPS data are spatially interpolated to the position of each leveling benchmark. The correlation coefficient is 0.69 indicating a good agreement between the two data sets. The result of linear fitting of both data is $V_{\mathrm{GPS}}=0.56 \times V_{\text {level, }}$ where $V_{\mathrm{GPS}}$ and $V_{\text {level }}$ are the vertical velocities derived from GPS and leveling, respectively. 
を描いた. Fig. 5 からは, 北海道太平洋岸の沈降, 東北 地方太平洋岸の沈降, 朝日飯豊山地付近の隆起, 四国加 ら紀伊半島にかけての隆起などが読み取れ, Fig. 3 およ びFig. 4 との間に類似性が見られる.

このように, 日本列島の上下変動の骨格をなすパター ンは, GPS と過去の水準測量結果とで共通している.こ のことは, 最近 100 年間で, 基本的な上下変動のパター ンに大きな変化がなかったこと, GPS 連続観測は 7 年 程度の短期間でもわが国の上下変動の特徴をよくとらえ ていることを示している.

ここで, 数値的な比較が可能な, Fig. 4 の水準測量結 果に戻る. Fig. 3 と Fig. 4 の空間パターンには, 全体的 な共通性があるが, 特に, 東北日本において上下変動分 布が酷似している. 緯度 37 度から 41.5 度の間の東北地 方に位置する約 940 点の水準点における水準測量結果 と GPS との相関を Fig. 6 に示す．観測点の位置が同一 ではないので, GPS 結果を水準点の位置に空間的に内 挿して, 両者を比較した. なお, 著しい地盤沈下地帯で ある新潟市周辺のデー夕は除去した，図でわかるよう に, 両者の相関は高く, 相関係数は 0.69 である. また,
直線近似による傾斜は 0.56 であり, 全体として水準測 量による上下変動速度の絶対值が大きい傾向が認められ

る. 原因はよくわからない.

一方, 全国における相関の様子を Fig. 7 に示す. 全体 の相関係数は 0.31 である. 図中の $\mathrm{A} \sim \mathrm{H}$ の楕円で示す ように系統的な差異をもつグループがある. A〜 Gの楕 円で囲んだグループは都市部の地盤沈下地帯であり, そ れぞれ, $\mathrm{A}$ : 名古屋市周辺, $\mathrm{B}$ : 大阪市周辺 $\mathrm{C}$ : 佐賀市周 辺, D: 東京都および川崎市周辺, $\mathrm{E}$ : 大宮市周辺, $\mathrm{F}$ : 新 潟市周辺, G: 埼玉舁幸手市・栗橋町周辺に対応する.こ れらは, いずれも 1960 年代を中心として地下水の汲み 上げによる地盤沈下が激しかった場所であるが，その対 策としてとられた揚水規制などの効果により，近年では 沈静化している. 沈静化以後に測定された GPSによる これらの地域の沈降速度は水準測量に比べて系統的に小 さい.

例えば，新潟市周辺では，地盤沈下のモニタリングの ため, 毎年水準測量が行われているが, 新潟市東部に位 置する 1 等水準点 4,421 は, 1960 年代の前半には, 1 年で $20 \mathrm{~cm}$ 近く沈降していた. 最近の沈降は 10 年間で

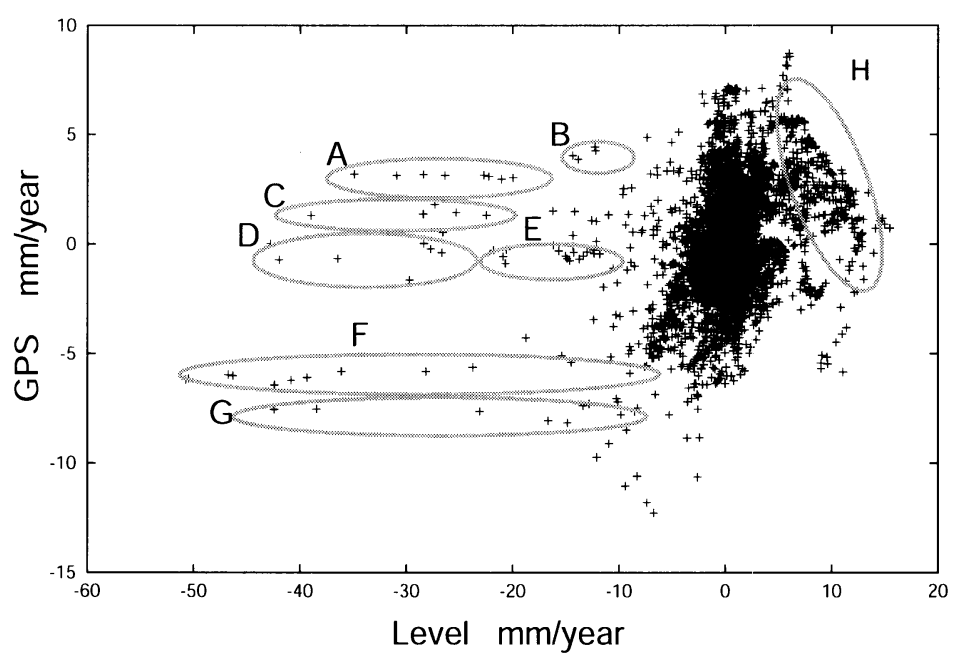

Fig. 7. Correlation plots of the vertical velocities by leveling and GPS. Unit of the velocity is in mm/ year. The GPS data are spatially interpolated to the position of each leveling benchmark. Velocities of most sites are within $+/-1 \mathrm{~cm}$ range except about 100 sites whose leveling velocities show large subsidence. The correlation coefficient for all the stations is 0.31 . The outlying data enclosed by ellipses $A$ to $G$ are located in the areas where significant ground subsidence was caused by retrieval of underground water during past several decades. We can relate the location of sites in group A to Nagoya city, B to Osaka city, C to Saga city, D to Tokyo and Kawaseki cities, E to Ohmiya city, F to Niigata city and G to Satte and Kurihashi cities, respectively. The ground subsidence declined after effectuation of legislative control of water retrieval. In most areas the subsidence rate is about $1 / 10$ of the maximum value in 1960's. The discrepancy between GPS and leveling in $\mathrm{A}-\mathrm{G}$ can be attributed to the difference of subsidence rate at the time of measurement. The group $\mathrm{H}$ corresponds to stations in Shikoku and Kii peninsula where leveling data is dominated by postseismic deformation due to 1944 Tonankai and 1946 Nankai earthquakes. 


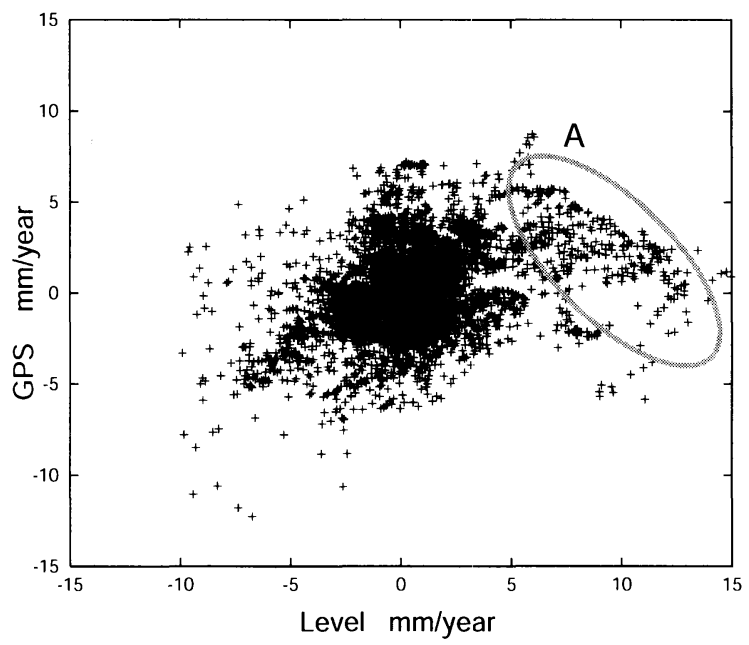

Fig. 8. Correlation plots between vertical velocities by leveling and GPS after removal of outliers as enclosed by the ellipses A-G in Fig. 7. The group $\mathrm{A}$ in this figure corresponds to the ellipse $\mathrm{H}$ of Fig. 7 . The correlation coefficient of all the stations in this figure is 0.35 . It becomes 0.39 after the removal of the data in the ellipse A.

$2 \mathrm{~cm}$ 程度となっており [国土地理院 (2003b)]，地盤沈 下の沈静化を示している. 本論文の GPS 結果もそれと 符合する.

また，楕円 $\mathrm{H}$ で囲んだ地域は，1944 年東南海地震お よび 1946 年南海地震後の余効变動の影響を大きく受け た地域である [例えば，吉岡 (1999)]．地震直後の期間を 含む水準測量の結果には余効変動が大きく寄与している が，時間とともにしだいに消滅し，現在はプレート間 カップリングが回復したことによる影響が支配的になっ ている (第 6.6 節参照)。このような理由からこの地域 では GPS 結果と水準測量結果との間に系統的な違いが 見られる.

Fig. 8 には, Fig. 7 の A〜G の楕円で囲んだ約 100 点 を除去した残りの約 4800 点の相関を示す．全体の相関 係数は, 0.35 である.なお，この図の楕円 A は Fig. 7 の 楕円 $\mathrm{H}$ に相当する. この楕円内の点を除いた残りのサ ンプルの相関は 0.39 である.これまで見てきたように, 東北地方の相関が特に良いが, 全国的に見てもある程度 の相関がある.

\section{§5. 他の観測との比較}

\section{1 験潮データとの比較}

次に, 験潮デー夕との比較を行う.Fig. 9 に, 全国約 100 力所の験潮場に拈ける上下变動速度と, GPSによ

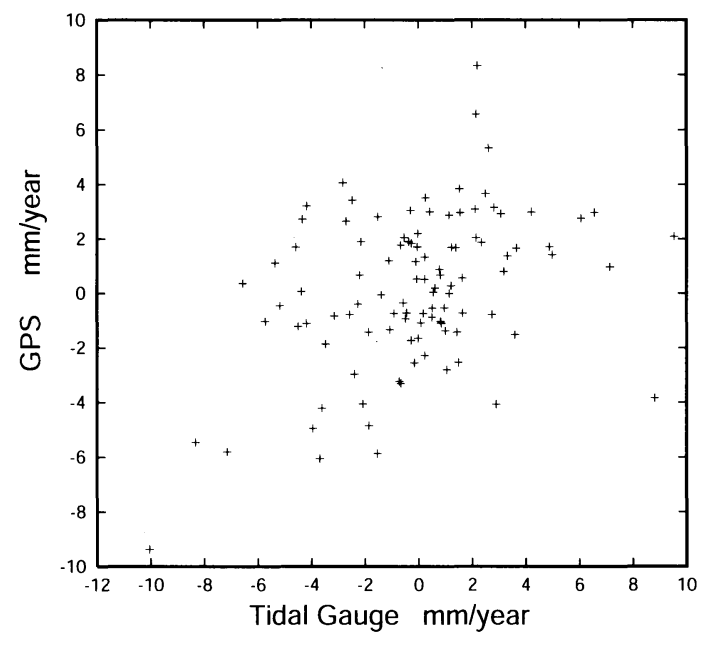

Fig. 9. Correlation plots between vertical velocities by tidal record and GPS. Vertical velocities derived from tidal records at about 100 sites are compared with the GPS velocities. The GPS data are spatially interpolated to the position of each tidal gauge station. The correlation coefficient is 0.39 indicating a reasonable agreement between them.

る変動速度の相関を示す. 験潮による上下变動は, 潮位 データの月平均値の一次傾斜を計算し, 符号を反転した ものである. 直線近似の䛊差は観測期間の長さに左右さ れるが, 近似後の残差 (約 $10 \mathrm{~cm})$ と観測期間 $(10$ 年か ら数十年) から計算して, 概补 $0.5 \sim 3 \mathrm{~mm} /$ year 程度と 見積むることができる. Fig. 9 は, GPS の上下変動から 内捚によって験潮場の上下変動を求句, 験潮結果と比較 した結果である. 全国の験潮場全体で計算した相関係数 は 0.39 となった. 験潮場は数む少なく, 海岸線に沿って しか分布していない極めて限定的なデータではあるが, GPS 結果と, 大局的に一致している.

\section{2 地形学的成果との比較}

最後に, 地形学的に推定された, より長い時間スケー ルでの日本列島の上下変動との比較を試みる. 貝塚・他 (1986) は, 地形学的立場から第四紀に起こった日本列島 の大局的な上下変動を論じている. 彼らの地形学的な分 類に従い, 第四紀に隆起した地域と沈降した地域を赤之 青に着色して Fig. 10 に示す. GPS による隆起・沈降の 分布は, 概柇彼らの結果と整合している. 特に, 東北地 方日本海側の隆起, 紀伊半島から四国にかけての太平洋 側の隆起, 関東地方の沈降などにおいて, 両者の類似性 が高い.

その一方で, 両者の傾向が明らかに異なる地域があ 


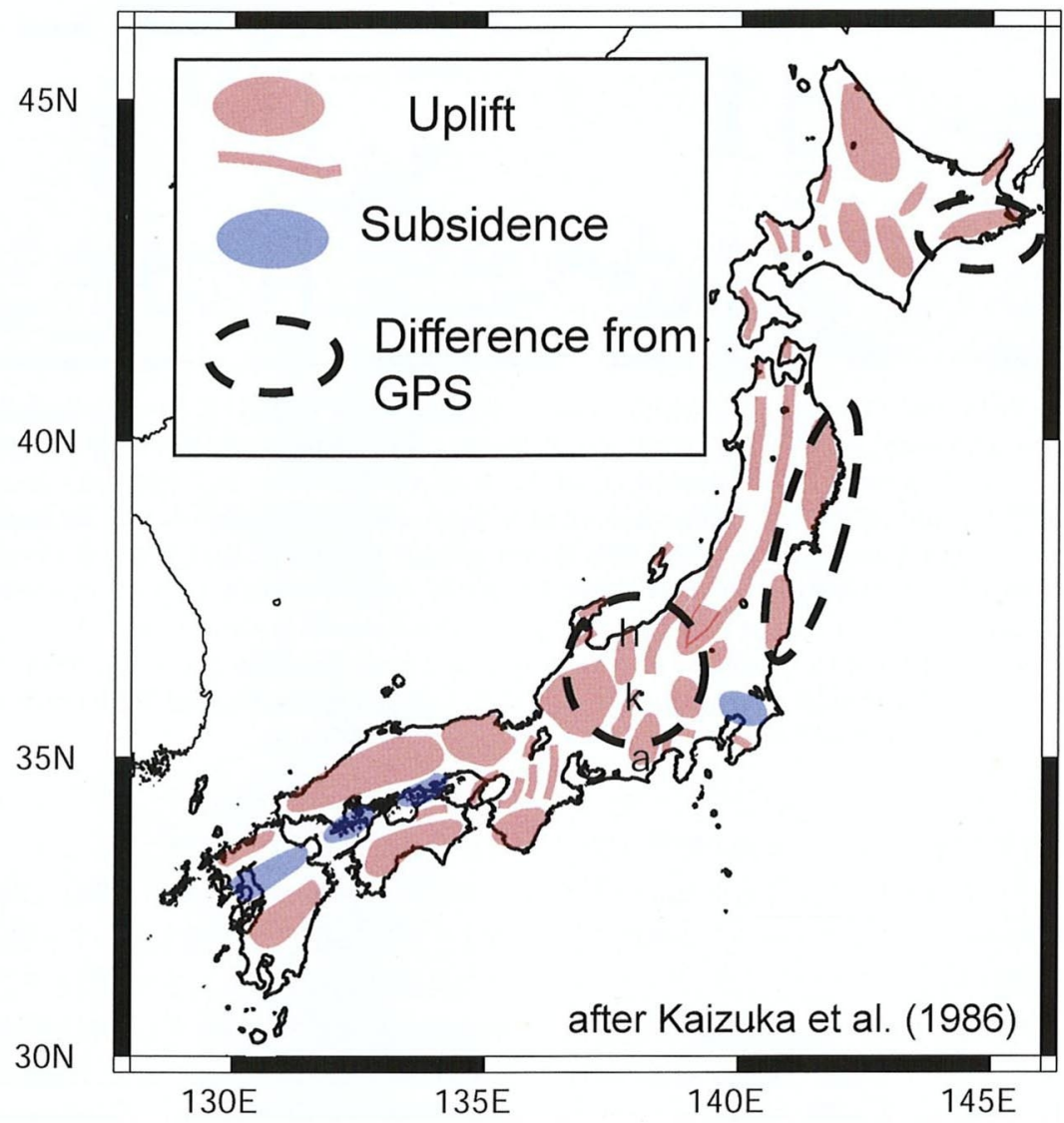

Fig. 10. Distribution of vertical deformation derived from geomorphologic analysis by Kaizuka et al. (1986). Areas colored in red show uplift, whereas ones in blue show subsidence. The areas indicated with broken ellipses show discrepancy between geomorphologic and GPS results. Letters, ' $h$ ', ' $k$ ', and 'a' indicate Hida, Kiso and Akaishi mountains.

る。それらは, 北海道東部の太平洋沿岸, 東北地方の太 平洋側, および図中に $\mathrm{h}, \mathrm{k}$, および a で示した飛騨山脈, 木曽山脈，赤石山地を中心とする中部山岳地域である. 地形学的的解析から第四紀を通じた隆起が支配的であっ たとされる同山岳地域において, GPS は相対的な沈降 を示しており，両者が一致しない，これについては，第 6 章でより詳細に考察する.

\section{§6. 議論一GPS による上下変動分布の特徵とテクト ニクスなどの議論へもたらす意義一}

以上のように, GPS による上下変動結果は, これまで に知られている水準測量等の測地学的成果や地形学的成 果と概ね調和的であり，GPSによる上下变動に一定の 信頼性があることを示している.

一方, GPS 之他の観測結果とが, 系統的に異なってい る場所がある. GPS は，各点の観測が個々に独立であ る. 気象などの現象で短期間に限机，共通の誤差をも
つ場合はあるが，広い領域の点が，長期にわたって共通 した誤差をむつ可能性は極めて低い. GPS 結果に一定 の信頼性を認めた前章までの検討結果を踏まえると, 過 去の観測との不一致が見られた場合, 上下变動の傾向の 経時的な变化を示しているか，そうでない場合は，むし ろ過去の観測に何らかの誤差が含まれていたと考えるべ きである. GPS はほほ均一に全国を覆っており，空間的 に均等な密度で上下変動の詳細な空間分布を知ることが できるようになった意義む大きい，次の節からは，GPS によりもたらされた上下変動に関する新しい視点につい て，主要なるのを取り上げ議論する.

\section{1 北海道東部の太平洋岸沿いの沈降}

Fig. 3 およびFig. 4 において明らかなように, 北海道 東部の太平洋側に面した広い領域が大きく沈降してい る. 根室市付近の花咲および釧路の各験潮場の観測結果 あ, 観測か開始された 1960 年代以降, それぞれおよそ $1 \mathrm{~cm} /$ year の速度で継続的な沈降が進行していること 


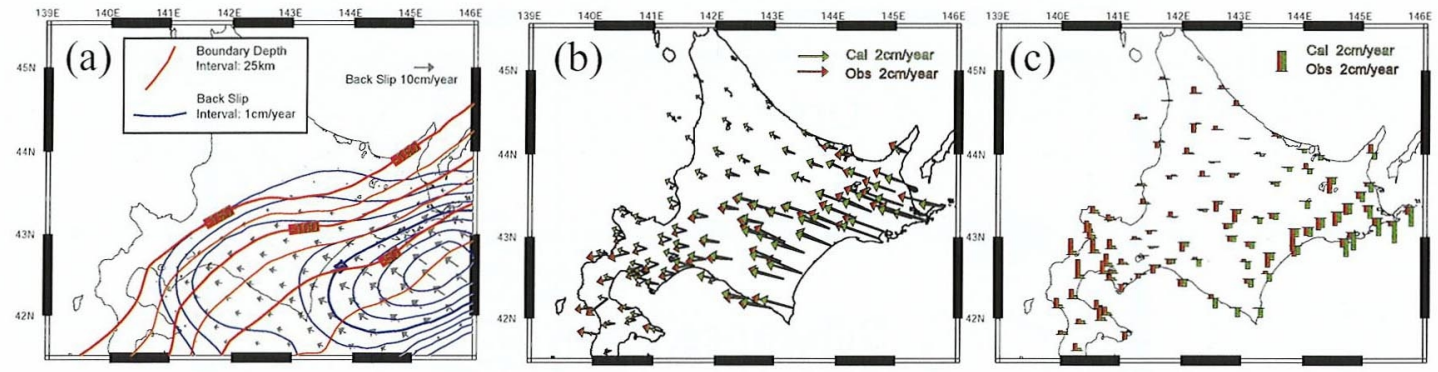

Fig. 11. (a) Distribution of backslip [Savage (1983)] derived form GEONET on the boundary surface between the continental plate and subducting Pacific plate during an interseismic period (19971998). Vectors in gray show distribution of back slip. Red contours show the depth of plate boundary [Katsumata (2003)] in km, whereas blue contours show magnitude of estimated backslip ranging from $1 \mathrm{~cm}$ /year to $8 \mathrm{~cm} /$ year. We inverted both horizontal and vertical velocity by GPS to obtain backslip distribution on the assumed plate boundary surface using a method by Yabuki and Matsu'ura (1992). In this inversion we strongly constrained a smoothness of slip distribution. The backslip to the depth of about $80 \mathrm{~km}$ is necessary to simulate the subsidence observed in southern coast of Hokkaido as seen in Fig. 3. (b) Simulated and observed horizontal velocities at GPS sites. (c) Simulated and observed vertical velocities at GPS sites.

を示している [国土地理院 $(2003 a)$. 変動の範囲が広い ことから，地盤沈下の影響があるとしてもそれは部分的 であり，主要な原因は何らかのテクトニックな機構によ るものである可能性が高い.

沈降と隆起の境界線は，火山フロントに沿って海溝軸 とほぼ平行に走っており，上下変動の原因が基本的には プレートの沈み込みにあることを強く示唆している．そ こで，以下において，太平洋プレートの沈み込みによる メカニズムの妥当性を検討する.

GPS による 1997〜1998 年間の水平および上下変動 データを用いて，プレート間カップリングを推定するイ ンバージョンを行った. 対象とした時期は, 地震間（interseismic 期）に相当し, 大きな地殻活動イベントはこ の間に発生していない. 期間が短いため, 年周などによ る影響が若干残っている可能性はあるが，概略の傾向を 見るには十分である. 北海道東部の沈降の忠実な再現を 念頭におきながら, Yabuki and Matsu'ura (1992)の方 法で，バックスリップ分布 [Savage (1983)] が滑らかに つながるようにやや強い拘束をかけてインバージョンを 行った. その結果を Fig. 11(a)〜 (c) に示す.

Fig. 11(a) は，推定されたプレート境界上のバックス リップ分布, Fig. 11(b) は水平変動の観測值之計算値の 比較, そして Fig. 11(c) は上下変動の観測值と計算値の 比較である. 北海道東部における沈降を陸域まで及ばせ るためには, カップリング領域の下端を深部方向へ相当 深く延長する必要がある. Fig. 11(a) は, フルカップル 時の $1 / 4$ である $2.5 \mathrm{~cm} /$ year のバックスリップが分布 する深さが, 北海道東部においておよそ $80 \mathrm{~km}$ に達し

\section{ていることを示している}

深部カップリングを考察する場合, 2003 年十勝沖地 震発生後の余効すべり分布が極めて示唆に富んでいる. この地震は, GPSによって地震前からの地殻変動が克 明にとらえられてた初めての巨大海溝型地震である.

Fig. 12(a)〜(d) は, Ozawa et al. (2004a) が明らかにし た地震時および地震後のプレート間すべり分布である.

Fig. 12(b)〜 (d) に示されるように，地震直後の 2003 年 9 月から 2004 年 3 月までの約半年間の余効变動による すべりは，地震時にすべった領域の外側に，ドーナッ状 に分布している．ここでは深部方向の余効すべり分布に 注目するが，その深さは約 $80 \mathrm{~km}$ 程度にまで達してい る. 余効すべりの向きは, 地震時とほぼ同じ南東方向で ある．このような余効すべりが生じるためには，地震発 生以前に, 応力が蓄積されることが必要である. Fig. 12 の余効すべりの分布は, $80 \mathrm{~km}$ 程度の深さまでの固着を 示していた Fig. 11(a)のモデルと符合する.

地震前に蓄積した可能性のある歪と解放された歪が量 的にバランスしていないことも重要である. Fig. 11(a) のモデルは, 地震間のバックスリップ量を深さ $80 \mathrm{~km}$ 付近で約 $2.5 \mathrm{~cm} /$ year と見積むっている. 一方， 2003 年十勝沖地震の余効变動として地震後約半年に解放され たフォワードスリップ量は, Fig. 12(d)によれば約 50 $\mathrm{cm}$ である. 地震の間隔を 100 年と仮定すると [地震調 查委員会 (2003)], 地震間に蓄積されたスリップ量は $2.5 \mathrm{~m}$ となるが, 余効変動ではその $20 \%$ 程度しか解放さ れていない. また，Fig. 12(a) は，深さ $80 \mathrm{~km}$ の領域が 地震時にほとんどすべっていないことを示している。し 

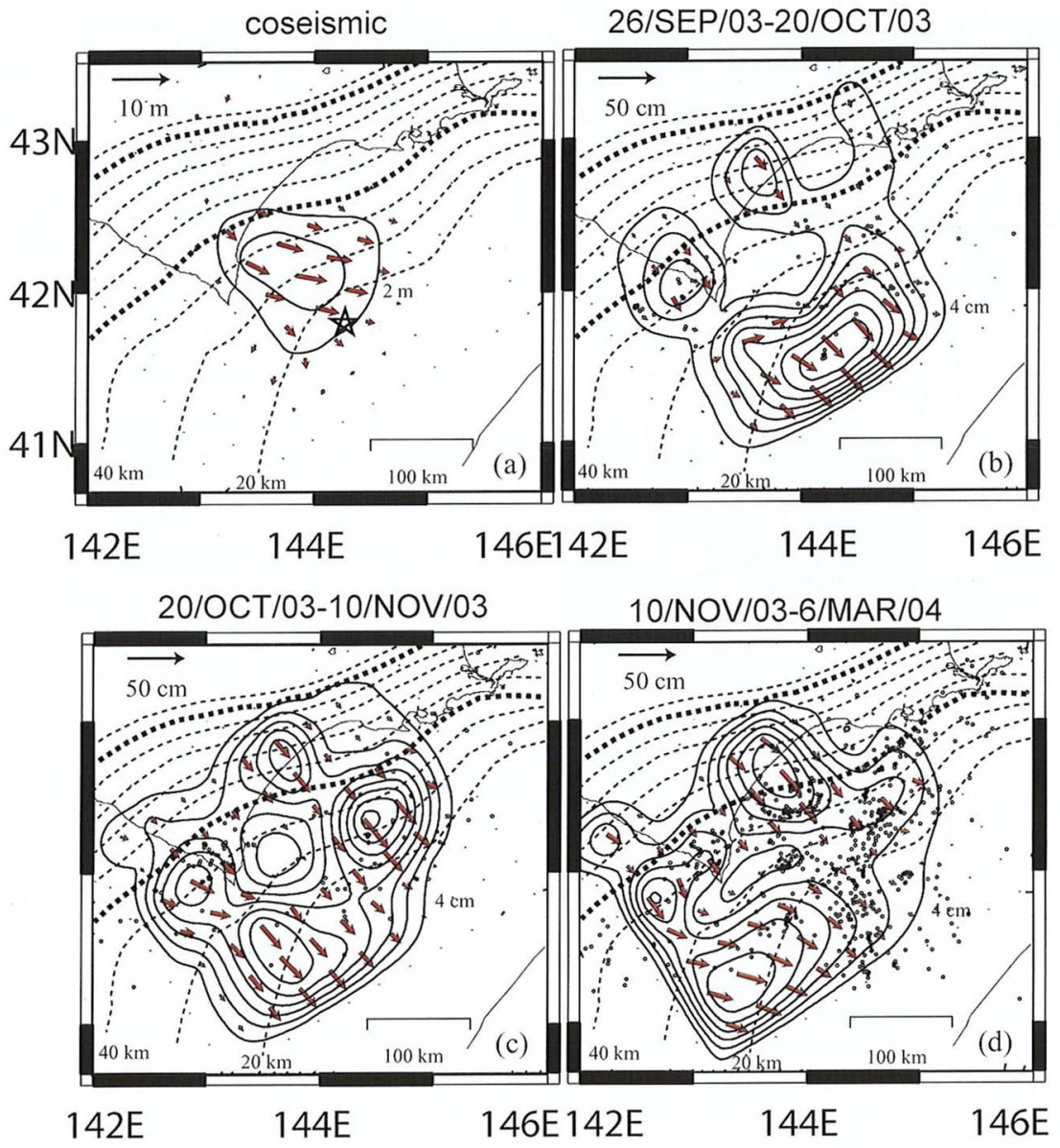

\section{after Ozawa et al. (2004)}

Fig. 12. Estimated distributions of coseismic and postseismic slips of 2003 Tokachioki earthquake (M8.0). Open circles represent aftershocks (Data from the Meteorological Agency of Japan). Broken lines represent isodepth contours of the plate boundary with $10 \mathrm{~km}$ intervals. (a) Coseismic slip distribution. The star represents the epicenter of the 2003 Tokachi-oki earthquake as identified by the Meteorological Agency of Japan. Contour interval is $2 \mathrm{~m}$. (b) Postseismic slip for the period September 26-October 2, 2003. Contour interval is $4 \mathrm{~cm}$. (c) Postseismic slip for the period October 2-November 10, 2003. Contour interval is $4 \mathrm{~cm}$. (d) Postseismic slip for the period November 10, 2003-March 6, 2004. Contour interval is $4 \mathrm{~cm}$. As of November 10, 2003 postseismic slip at the depth of $80 \mathrm{~km}$ reaches about $50 \mathrm{~cm}$.

たがって，これまでのところ，深部における歪収支は消 費より蓄積が圧倒的に勝っている，地震間に深部で蓄積 された歪の解消過程には, いくつかの可能性がありう る. 最悪の場合として，急激に解放される過程を想定す ると，巨大な地震または津波地震の発生の可能性が浮上 する. 津波堆積物の解析から, 千島海溝沿いの超巨大地 震の可能性が検討されているが [例えば, Nakayama et al. (2003)], 上下変動の解析は, このような議論とも関
連して，さらに詳細に実施される必要がある。

Fig. 3 は, 日高山脈の相対的な隆起を示している. 例 えば Table 1 の No. 6 「えりあ $2 」$ は, $1.1 \mathrm{~mm} /$ year の 速度で隆起している。地形学的解析から屯, 日高山脈は 15 万年前から現在に至るまで隆起しているとされてお り [吉山・柳田 (1995)], 本結果と調和的である. また, 浦河や十勝港など，日高山脈付近の験潮記録［国土地理 院 (2003a)］ む同様の傾向を示していることから，この 
地域の隆起が真実である可能性が高い.

この隆起は, その東隣の帯広や釧路周辺の沈降とは際 立った対照を見せており, 選択的に日高山脈を隆起させ る何らかのメカニズムが作用しているはずである。 その

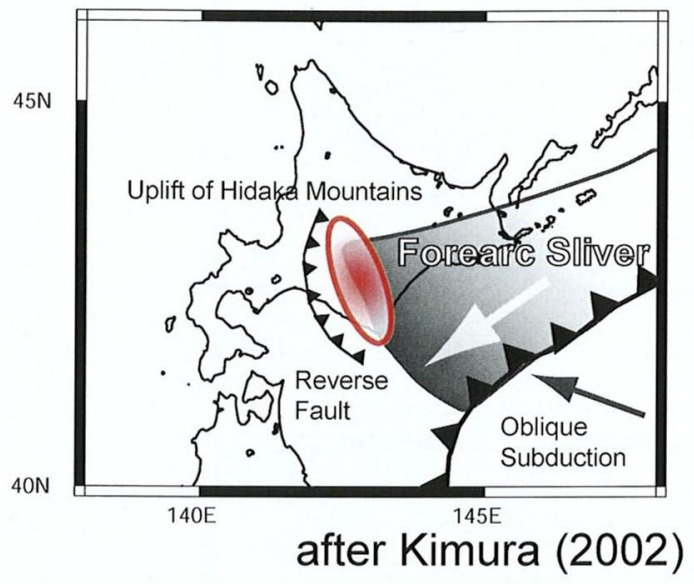

Fig. 13. Schematic illustration of a forearc sliver model along the Kuril Trench by Kimura (2002). An oblique subduction of the Pacific plate produces a southwestward dragging force acting on a forearc region along the trench, which is called a forearc sliver. Because of bending of the Kuril trench offshore cape Erimo, the forearc sliver collides onto a neighboring block sitting in the west. This collision results in a uplift of Hidaka mountains.

\section{Principal Strain Axes Distribution}

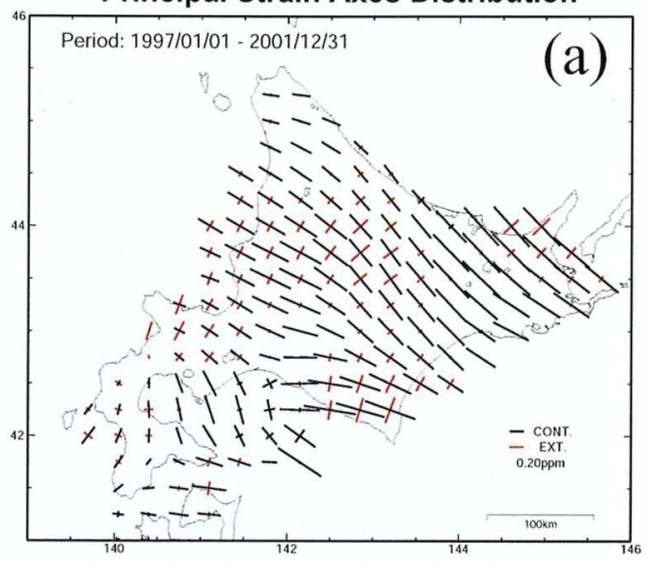

有力な候補の一つとして，木村 (1981) による前弧スリ バーの衝突の考え方がある. Fig. 13 に, 簡略化したスリ バーモデルを示す. 太平洋プレートの斜め沈み込みに よって, 前弧部には海溝軸に平行な方向（南西方向）の 力が加わり, その結果, 前弧スリバーとよばれる細長い ブロックが海溝と平行に南西方向に移動する. 襟裳岬沖 で海溝は南向きに方向を変えるため, 前弧スリバーの南 西端は，それ以上南西に進めず，それより西のブロック との衝突が起こる.この衝突によって日高山脈が隆起す ると考えられている [木村 (1981)].

このメカニズムが実際に機能しているとすると, その 影響は, 水平変動分布にも現れることが期待される.

Fig. 14(b) は, GPS の水平成分から計算したせん断歪の 分布であるが，せん断歪の集中する領域が火山フロント に沿って東西方向に走っている．この地域は，スリバー と背弧側のブロックとの境界に相当し, 温度の高い火山 フロント下の地款で延性的な変形が起こり[木村 (2002)]，せん断歪が集中する帯状の領域となっている 可能性がある.

一方, Fig. 14(a) は北海道地方の水平主歪の分布であ る. 北海道の中央部を含む東半分では, 軸の方向が千島 海溝之直行する北西南東方向を向く圧縮が支配的である が，日高山脈の西の領域だけ，圧縮軸が東西方向に振れ ている．南西向きに移動する前弧スリバーが西のブロッ クに衝突する結果，日高山脈付近では北東南西方向の圧 縮の成分があたらされ，それによって，広域的に分布す

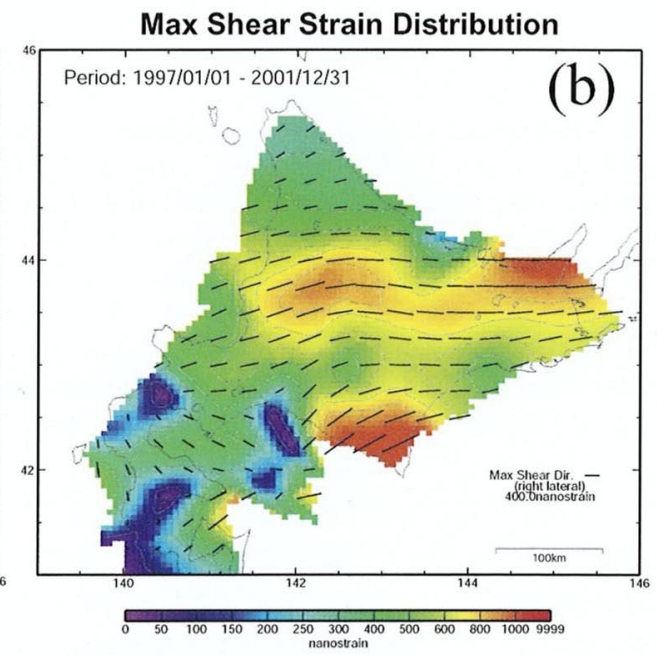

Fig. 14. Horizontal strain field in Hokkaido derived from the GPS measurements. (a) Distribution of horizontal principal axes in Hokkaido derived from GEONET data during 1997-2001 using a software package for geodetic data post processing [Sagiya et al. (2003)]. (b) Distribution of horizontal shear strain in Hokkaido derived from GEONET data during 1997-2001. In the eastern Hokkaido a belt with high shear strain rate lies along the volcanic front. 
る北西南東方向の圧縮軸が，ここだけ東西方向に向くよ うにシフトさせられていると解釈できる．このように， 水平歪の分布も, 前弧スリバーの衝突による日高山脈隆 起の仮説を支持している.ここまでの議論では, 地震サ イクル中の地震間 (interseismic) に相当する期間のデー 夕を使用しておう, 日高山脈がこの期間, 相対的に隆起 している可能性が高いこと, その隆起は前弧スリバーモ デルによって説明可能であることが示された.

しかし，議論の対象期間を，地震サイクル全体に拡大 しょうとすると，新たな疑問に直面する．2003 年十勝 沖地震時には, 襟裳岬は約 $22 \mathrm{~cm}$ 沈降している [Ozawa et al. (2004a)]. 地震前の隆起は, Table 1 に示すとお り, $1.1 \mathrm{~mm} /$ year 程度であり, この地震の再来周期が 80 年程度であることを考えると[地震調查委員会 (2003)], 地震間には, せいぜい $10 \mathrm{~cm}$ の隆起が蓄積す るだけである. 余効変動による隆起も, 現在までに $1 \sim 2$ $\mathrm{cm}$ 程度でありこれ以上大きくなる可能性は低い，地震 間の緩やかな隆起と余効変動を蓄積させるだけでは地震 時の沈降がカバーできない，地震サイクルがこのような 形で続いていくと, 地震のたびに襟裳岬付近は沈降し続 けることになってしまう。しかし地形学的には, Fig. 10 に示されるように, 日高山脈は長期的には隆起すべきで あり，両者は矛盾する，両方の観測事実を満足するため には, 襟裳岬付近を大きく隆起させる何らかのテクト ニックなイベントが必要である，それは必ずしあ，破局 的なむのである必要はないが，いずれにせよ, Nakayama et al. (2003) が北海道東部で検討しているような 巨大イベントにまで視野を広げ, 上下変動も取り入れた 議論が展開されるべきである.

これまで, $80 \mathrm{~km}$ 程度の深い領域にまで, 沈み込む太 平洋プレートの影響が及んでいるという仮説に沿って議 論を進め, 地震間時の北海道東部の沈降が説明可能であ ることなどを見てきた， しかし，地震間に限っても，そ れだけでは説明できない上下変動も残っている．例え ば, 根室半島周辺は， バックスリップ分布から予想され るとおり沈降が観測されているすのの, 量的には Fig. 11(a)のモデルから期待される大きさに達していない. ここでも，プレート間カップリングの効果に加えて，ま だ特定されていない別のテクトニックな機構が働いてい る可能性が高い，このように, 本論文の検討は, 初期的 なあので, この地域の上下変動のすべてを説明するに 至っていない. しかし, GPS による上下変動は, テクト ニクスの解釈にとって極めて重要かつ有効なデータであ り,これを用いることで今後さらに詳細な議論の進展が 期待されることが示された。

\section{2 室蘭, 登別, 苫小牧付近の沈降}

Fig. 3 およびFig. 4 は, 苫小牧から登別を経て室蘭に 至る太平洋側が沈降していることを示している. 苫小牧 市では, 過去の一時期, 地下水汲み上げにより, 市の北 部に局所的な地盤沈下が発生したものの，その後取水が 規制され，最近では地盤沈下が沈静化した之報告されて いる [環境省 (2002)]. 地下水汲み上げによる地盤沈下 は多くの場合局所的であり，その空間的な広がりは小さ い. 一方, Fig. 3 および Fig. 4 には，苫小牧からから登 別を経て室蘭に至る数十 $\mathrm{km}$ 程度の広い領域が, 系統的 に沈降している様子が示されている. 地盤沈下以外にも 何らかのテクトニックな原因が存在し，それによって沈 降が生じている可能性が高いが, その理解は十分進んで いない，今後の詳細な検討が必要である.

\section{3 渡島半島の日本海側（中心はニセコ付近）の隆起}

Fig. 3 は，二セコ付近を中心として渡島半島のほぼ全 体が隆起していることを示している. Ueda et al. (2003) は, この隆起を 1993 年北海道南西沖地震の余効变動に よるものとして説明している. 北海道南西沖地震前の地 壳変動が反映される Fig. 4 および Fig. 5 の水準測量結 果をみると, 渡島半島日本海側において, 隆起の傾向が 認められるものの, その大きさは Fig. 3 に比べて有意に 小さい，以上のことから，この隆起は北海道南西沖地震 後に始まった可能性が高い.この隆起は, Ueda et al. (2003) のように北海道南西沖地震の余効变動の影響で あると考えるのが妥当である.

\section{4 東北地方における日本海側の隆起および太平洋 側の沈降}

Fig. 3 において，東北地方では，大きく分けて太平洋 側が沈降し日本海側が隆起している. この傾向は, Fig. 4 および Fig. 5 の水準測量結果にも系統的に現れている ので, この地域で継続的に進行している地款変動を反映 していると考えられる.

太平洋側の沈降は, この地域でも北海道の太平洋側と 同様に, 沈み込む太平洋プレートの引きずりの効果が, かなり深い領域にまで及んでいる可能性を示唆する [諏 訪・他 (2004)]. ただし, 八戸周辺の三陸地方は, 太平洋 側でありながら隆起している。この場所は，1994 年三 陸はるか沖地震の震源域に近く, 地震直後には余効変動 による隆起が報告されており[例えば, Heki et al. (1997)], それが現在も続いている可能性がある. Fig. 5 の水準測量結果は, この地域が過去には沈降していたこ とを示しており, 隆起が最近の現象であることを示して いる.

日本海側に面した東北地方の西部は, 系統的な隆起が 顕著である. 太平洋プレートの沈み込みによる引きずり 
によって, 陸側プレートが弾性変形し, 内陸側が隆起し ている可能性がある。この場合は, 北海道の太平洋側と 同様, 太平洋プレートと上盤プレートの固着が境界の深 部に及ぶことが必要である [諏訪・他 (2004)]。一方, 地 形学的に推定されているように, 東北地方の東西圧縮の 結果生じる褶曲 [貝塚・他 (1986)] など累積的な塑性变
形の可能性むある. また, Aoki and Scholz (2003) は, 日本海側の新しい収束境界に起因する隆起の可能性を指 摘している。

東北地方の上下変動について，理解が十分進んでいる とは言えず, この地域のテクトニクスについても, 上下 変動を含めて詳細な検討がなされることが必要である.
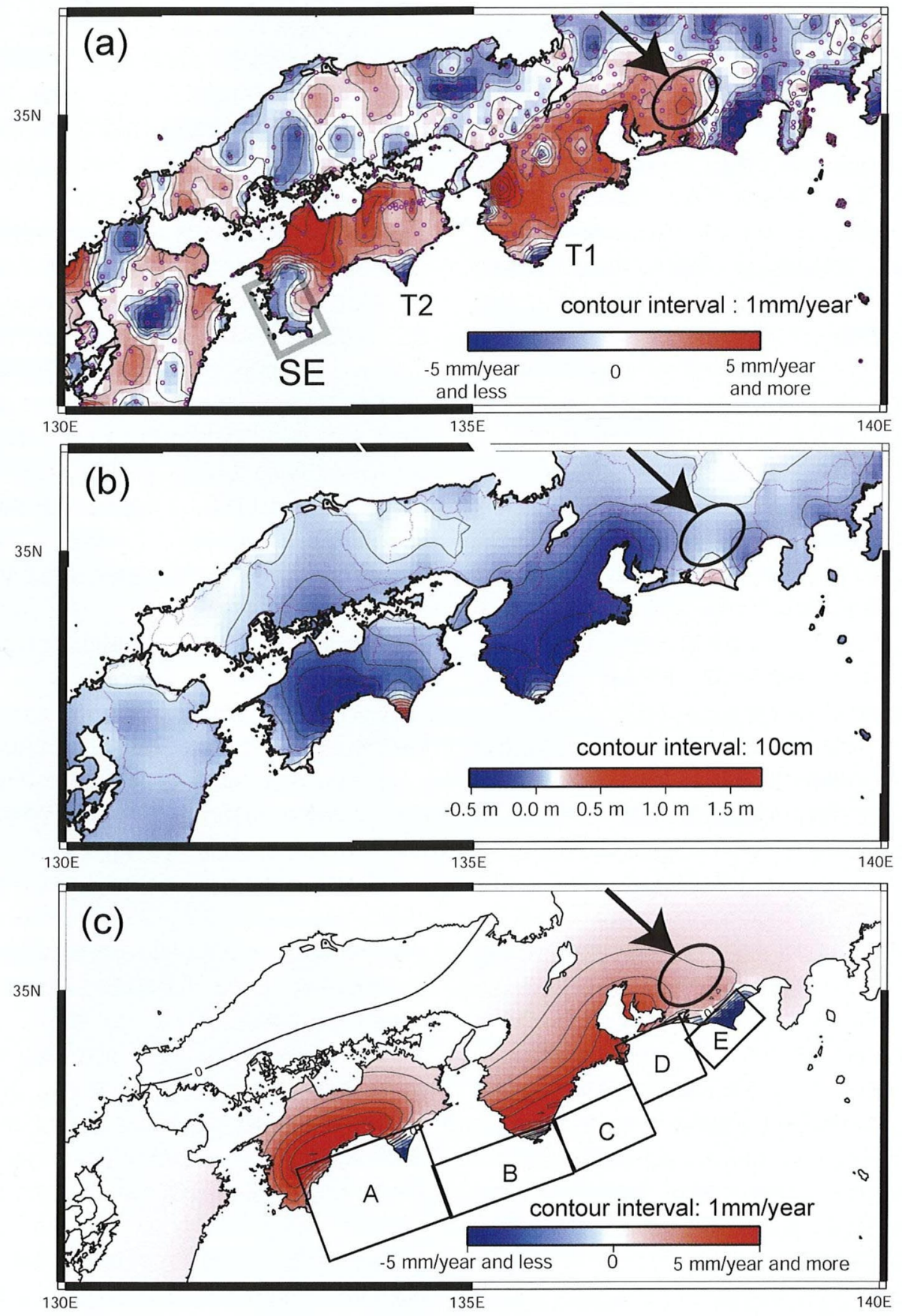


\section{5 中部山岳地域の沈降}

Fig. 3 は中部山岳地域一帯が沈降していることを示し ている. 地形学的には, 中部山岳地帯は百万年, あるい は数十万年前以降, 隆起したと考えられている [貝塚・ 他 (1986)]. Fig. 10 において “a”および “k”で示す赤石 山地, 木曽山脈は, 地形学的な証拠から, 現在でも隆起 が続いているとされている[森山(1990)]. また, 壇原 (1971) も, 赤石山地の西の伊那盆地を走る路線に沿った 水準測量結果を用い, Fig. 5 のように, 赤石山地付近を 中心とした南北に伸びる領域の隆起を推定している.

しかしながら, 中部山岳地帯に分布している GPS 点 の観測結果は, 飛騨山脈 (Fig. 10 の “h”), 木兽山脈, お よび赤石山地の主要部分を含む中部山岳地帯が全体とし て系統的に沈降していることを示している. 赤石山地の 西側には, 四国から紀伊半島を経て東に延びる帯状の隆 起地帯が見えるが，これが赤石山地の西部にわずかにか かっているだけで, 赤石山地や木曽山脈が全体として隆 起しているわけではない. この帯状の隆起の原因は, フィリピン海プレートの沈み込みによる上盤プレートの 弾性変形と考えられる (6.6 節参照). プレートの沈み込 みの影響で隆起が生じている場所は, 1944 年東南海地 震や 1946 年南海地震時に, 紀伊半島や四国が沈降した ように, プレート間巨大地震発生時に沈降する可能性が 高い. したがって, 現在隆起している帯状領域む, この ままの速度で隆起を続ける可能性は低い.

中部山岳地域における GPS の配置は, その多くが盆 地など低高度な場所であり, 山地に直接設置されている 点は極めて少なく, 山岳形成を本格的に論じるためには 不十分である. そのため, 観測網でカバーされていない
真の山岳部は観測にかかることなく隆起しているという 可能性が残る.しかしその場合でも, 山岳部に近い点は, より遠い点に比較して相対的に隆起していると予想され る.それがたとえ微小でも観測期間を十分取れば GPS はそれを検知する可能性が高い. 山岳形成メカニズムが 実際に作動している場合には, GPS の設置高度と上下 変動速度に相関があることが期待される。これを確認す るため, 中部山岳地帯に含まれる GPS 点の高度と上下 変動速度の相関を調べたが, 両者の間に相関は見られな かった. 直接的な否定ではないが, 山岳部のみが選択的 に隆起している可能性は低い.

中部山岳地帯で, 現在, 隆起が見られないことに対し て，いくつかの説明が可能である.

その第 1 は, 山地の形成はすでに終了し現在は隆起し ていないとするあのであり, 第 2 は, 長期的には隆起が が進行しているが, 摇らぎを伴っており, 現在は, 摇ら ぎの範囲内で生じうる偶々の沈降時期に相当するとする あのである. そのどちらかであるか, またそれ以外の解 釈が必要であるかは，現時点ではわからない。

いずれにしても山岳の形成は 100 万年程度の長期間 に進行する現象であり, 測地学的なデータだけで論じる ことには限界がある. 少なくとも地震サイクルを何度か 経た後に残留する地殻変動を知る必要があるであろう.

しかし, GPS による上下変動分布は, 山岳形成の議論に 拘束条件を与えることができるはずである，現在はその 出発点に立ったに過ぎず，このようなデー夕を長期間蓄 積することにより, 山岳形成のメカニズムが徐々に明ら かになっていくものと期待される.

Fig. 15. Vertical deformations in Southwestern Japan along Nankai Trough. (a) Vertical velocity by GPS during 1996-2003. It is inferred that the uplift in Shikoku and Kii peninsula is caused by an elastic deformation of the continental plate dragged by the subsiding Philippine Sea Plate. The tips of Kii and Muroto peninsulas, as indicated by $\mathrm{T} 1$ and $\mathrm{T} 2$, are subsiding. Recent precise leveling survey confirms the subsidence. GPS stations in the rectangle SE were uplifted during a slow earthquake event in 2003 [Ozawa et al. (2004b)]. During an interseismic period this region is subsiding as seen in this figure, suggesting a coupling between the plates. (b) Coseismic vertical deformation of the 1944 Tonankai and the 1946 Nankai earthquakes derived from precise leveling surveys before and after the earthquakes. The deformation field of figure is almost the opposite of that of Fig. 15(a), except for Tokai region, in such a way that the spatial pattern of vertical deformation is nearly the same but the sign is opposite. (c) A forward model of backslip distribution to simulate vertical field indicated in Fig. 15(a). Rectangles are planes where we assumed plate coupling. Parameters assumed in the simulation are listed in Table 2. We used fault geometry by Ishibashi (1981) for the 1944 Tonankai earthquake as indicated by rectangles C and D and by Ando (1975) for the 1946 Nankai earthquake as A and B. We assumed uniform backslip distribution by $5 \mathrm{~cm}$ /year on those areas. Additional coupling on rectangle $\mathrm{E}$ by $2.5 \mathrm{~mm} /$ year is necessary to simulate vertical pattern of Tokai region as marked by an ellipse. This confirms that the strain is accumulating over a segment of plate boundary that did not rupture during 1944 Tonankai earthquake episode [for example, Mogi (1970)]. 


\section{6 南海トラフ沿いの上下変動}

南海トラフに沿ってフィリピン海プレートが沈み込ん でおり, 東海沖から四国沖にかけて, 海溝型巨大地震が 繰り返し発生している.この沈み込みに伴う顕著な水 平・上下変動が観測されているが, 特に, 駿河湾西岸の 沈降は, 想定されている東海地震との関連から, 水準測 量や験潮などのデー夕によって詳しく検討されている. 国土地理院は, 駿河湾西岸の沈降を監視するため, 静岡 県森町と御前崎の間の水準測量を年 4 回の頻度で繰り 返している，その結果によれば, 御前崎は, 森町に対し ておよそ $8 \mathrm{~mm} /$ year の速度で, ほぼ定常的に沈降して いる [国土地理院 (2004)].

上下変動は，プレート間カップリングの分布を推定す る際に, 拘束条件として有効に衝くので, その詳細な分 布を知ることは極めて重要である，東海地方では，広域 的な水準測量についても, 国内の他の地域より高い頻度 で実施されている。しかし, この水準測量の実施頻度は, 毎年 1 回であり, それ以上に頻度を上げることは予算な どの制約から難しい，時間分解能を高めるために，GPS 上下変動データの利用に対する期待は高い. 以下におい ては, 定常的な変動について，まず理解するため，この 地域の最近 7 年間の平均的な上下变動を検討する.

Fig. 15(a) は，駿河トラフおよび南海トラフ沿いの領 域を拡大して, GPSによる上下変動分布を示した図で ある.なお, 3.2 節でも述べたように, 浜名湖周辺のゆっ くりすべり [Ozawa et al. (2002)] の影響は, この図から 除外されていない. しかし，その出現範囲は浜名湖周辺 に限られている，以下では，やや広域のテクトニクスを 検討することにして, 特に区別することなく議論を進め る.

Fig. 15(a) は, 御前崎から静岡にかけての駿河湾に面 した領域が沈降し, その背後が隆起していることを示し ている. また, 紀伊半島から四国にかけてトラフ軸に平
行に延びる $100 \mathrm{~km}$ 程度の幅の帯状領域が, 系統的に隆 起している.この領域は, Fig. 15(b) に示すように, 1944 年東南海地震抢よび 1946 年南海地震時に, 大き な沈降を示した場所であある. Fig. 15(a) と Fig. 15(b) をさらに詳細に比較すると，上下変動の分布が正反対に なっていることがわかる，地震時に隆起した潮の岬，室 戸岬が現在は沈降し，地震時に広く沈降したトラフに平 行な帯状の領域が, 現在は隆起している。これらのパ ターンは, 地震時に大きくすべったプレート境界上の領 域が, 現在は固着を回復し, 歪の蓄積が進んでいるとい うメカニズムで, 基本的には理解できる.

東南海地震および南海道地震の発生に伴い, 四国から 紀伊半島を経て伊勢湾に至る広い領域で歪が解放された が, 駿河湾周辺の東海地震想定域では, 歪が解放されて いないことが指摘されている[例えば Mogi (1970)].

Fig. 15(b) を見ると, 駿河湾西岸地域の地震時の上下変 動は小さく, 歪の解放が小さかったことが確認できる. また，現在の歪の蓄積を見るために，東南海地震および 東南海地震の震源モデル [Ishibashi (1981), Ando (1975)] の断層形状を仮定し, 地震時のすべりと逆向き のバックスリップを Table 2 のように想定して計算し た上下变動分布を Fig. 15(c) に示す. Table 2 の断層 $\mathrm{A} \sim \mathrm{D}$ は, 現在の固着を反映させるため, 東南海地震お よび南海地震の震源断層の位置に置いたバックスリップ である. 断層 $\mathrm{E}$ は, 駿河湾西岸の沈降と楕円で示した領 域の隆起を再現する目的で, 駿河湾の下のプレート境界 に新たに仮定したバックスリップである.

Fig. 15(a) と Fig. 15(c) の比較からわかるように，断 層 $\mathrm{E} て ゙$ 示される駿河湾下のプレート境界の固着域の存 在を仮定しないと，現在進行している駿河湾西岸の沈降 や，その内陸側の隆起が説明できない. Mogi (1970)の 指摘のように, 駿河湾周辺の歪は東南海地震時には解放 されていないこと，さらに，現時点において，この領域

Table 2. Parameters used in simulation of vertical deformation in the southwestern Japan as illustrated in Fig. 15(c). Geometric parameters of Tonankai and Nankai earthquakes are identical to focal models for them [Ando (1975), Ishibashi (1981)]. Backslip on rectangle E is necessary to simulate the observed vertical deformation in the Tokai region.

\begin{tabular}{lccccccccc}
\hline & $\begin{array}{c}\text { Longitude } \\
(\mathrm{deg})\end{array}$ & $\begin{array}{c}\text { Latitude } \\
(\mathrm{deg})\end{array}$ & $\begin{array}{c}\text { Depth } \\
(\mathrm{km})\end{array}$ & $\begin{array}{c}\text { Length } \\
(\mathrm{km})\end{array}$ & $\begin{array}{c}\text { Width } \\
(\mathrm{km})\end{array}$ & $\begin{array}{c}\text { Strike } \\
(\mathrm{deg})\end{array}$ & $\begin{array}{c}\text { Dip } \\
(\mathrm{deg})\end{array}$ & $\begin{array}{c}\text { Rake } \\
(\mathrm{deg})\end{array}$ & $\begin{array}{c}\text { Backslip } \\
(\mathrm{m} / \text { year })\end{array}$ \\
\hline $\mathrm{A}(1)$ & 134.75 & 32.68 & 0 & 150 & 120 & 250 & 20 & -63 & 0.05 \\
$\mathrm{~B}(1)$ & 136.25 & 33.13 & 0 & 150 & 70 & 250 & 25 & -63 & 0.05 \\
$\mathrm{C}(2)$ & 137.25 & 33.53 & 3 & 100 & 70 & 245 & 24 & -67 & 0.05 \\
$\mathrm{D}(2)$ & 137.87 & 34.14 & 20 & 80 & 80 & 245 & 24 & -67 & 0.05 \\
$\mathrm{E}$ & 138.58 & 34.71 & 0 & 80 & 50 & 225 & 25 & -80 & 0.025 \\
\hline
\end{tabular}

(1) The 1946 Nankai Earthquake $(M=8.0)$ [Ando (1975)].

(2) The 1944 Tonankai earthquake $(M=7.9)$ [Ishibashi (1981)]. 
では歪の蓄積が進行していることが上下変動からも確認 できる.

Fig. 15(a)においては, 四国西部む注目すべき場所で ある. 四国南西部のやや広い領域が, 沈降している.こ の地域では, プレート境界上でゆっくり地震が発生して いる [Ozawa et al. (2001), Ozawa et al.(2004b)]. ゆっく り地震時には四国西部の点は隆起している. 例えば, 2003 年に発生したゆっくり地震時には Fig. 15(a)の長 方形 SE で囲む領域の GPS 点が隆起した. Ozawa et al. (2004b) の解析でプレート境界上でゆっくり滑ったとさ れている領域のほぼ真上の地表が隆起している.ゆっく り地震時にエネルギーが解放されるためには，それ以前 に何らかの機構で歪エネルギーが蓄積されることが必要 である. 上盤プレートが沈み込むフィリピン海プレート に引きずられて変形し, 歪エネルギーが蓄積している可 能性が最も高い. それが正しいとすると, ゆっくり地震 時に隆起する四国の南西部の点は, 地震間には沈降して いるはずである．Fig. 15(a)では, 豊後水道のゆっくり 地震の影響がある期間は除外して速度を計算している. 図には, ゆっくり地震時に隆起した領域 SE が沈降して いる様子が明瞭に現れており,ゆっくり地震が発生して いない期間は, 同じ領域でプレートが固着していること を示している. ゆっくり地震時のスリップが分布する深 さは, $40 \mathrm{~km} よ り$ 深い[Ozawa et al. (2004b)] ので, こ れらの結果を総合すると, 足摺岬を挟んで南海トラフ沿 いのプレート間カップリングは, 東西で様相を異にする ことが示唆される. 南海地震の震源域でもある足摺岬の 東では, カップリングはせいぜい $30 \mathrm{~km}$ 程度までしか 及んでいないが, 西部ではより深部がカップリングして いるように見える. この地域は, プレートの屈曲部に面 しており，それが南海トラフ沿いの他の地域とは違った テクトニクスをもたらしている可能性があり, 繰り返し 発生するゆっくり地震との関係を含めて, さらに詳細な 検討が期待される.

\section{7 新潟から神戸にかけての地殼水平歪集中ベルト の沈降}

GPS 連続観測網がもたらした重要な知見の一つに, 新潟から神戸に至る歪集中ベルトの存在がある [Sagiya et al. (2000)]. これは, 大局的には東西圧縮の場にある 日本列島の水平歪速度の分布が一様ではなく，より大き く変形している領域とそれほど変形していない領域が混 在しており，そのような歪集中領域の一つが新潟から神 戸にかけて帯状に分布しているというものである．彼ら は, 活断層分布や地震活動の空間分布とも符合すると指 摘している. この歪集中帯では, 東西の圧縮が卓越して いる.
この場合のように，水平に圧縮された地殼ブロックが 変形する場合, 水平方向に短縮して, その結果, 上下方 向に厚みを増すこよが予想される. しかしながら，GPS によって得られた上下変動分布は, 必ずしもその予想ど おりにはなっていない. この水平近く丕集中帯は, 隆起 しておらず，むしろ沈降が卓越している. 水平に圧縮さ れながら, しかも同時に沈降するという, 複雑な現象が 進行していることを示唆している. 最近, 鷺谷・井上 (2003) は, アイソスタシーを考慮すると, 横方向の圧縮 によって厚みが増しても, それが隆起となって現れるの は全体の数分の 1 であるとし, 隆起が顕著でなくてあよ いと説明しているが, GPS 上下変動の成果は, 歪集中帯 がその周囲に比べて相対的に沈降していることを示して おり，アイソスタシーの作用だけですべてを説明するの は難しい.

\section{8 阿蘇カルデラ周辺の沈降}

Fig. 3 では, 九州の中央部に沈降域が見られる.この 領域では, 阿蘇カルデラ内のすべての観測点（3点）と 九重山近傍にある観測点が沈降しており, 図には, これ が反映されている. 水準測量結果に基づくFig. 5 にも， ほぼ同じ場所に沈降が示されており, 壇原 (1971) は, 真 実の変動である可能性が高いと判断している. より新し い水準測量結果に基づくFig. 4 には, 沈降域は現れてい ないが,このときは水準測量の路線が阿蘇カルデラを 通っていないので, 否定の材料とはならない. 沈降が Fig. 3 および Fig. 5 に共通に現れており, 系統性および 継続性のある変動であることが強く示唆される.この地 域は, 別府島原地溝帯が走る地域とも重なるが, 地溝帯 に含まれる別府や熊本には顕著な沈降がないこと, 特に 阿蘇山周辺の沈降はカルデラ内に限られることから, 地 溝帯全体が沈降しているのではなく, 阿蘇山カルデラお よび九重山に関連する火山性の沈降である可能性が高 い.

\section{§7. ま とめ}

これまで用いられることの少なかった，GPSの上下 成分から日本列島の上下変動分布を求めた. 水準測量結 果, 験潮結果および地質学・地形学的知見との比較から GPS による上下変動の信頼性が高いことを確かめた. GPS 点の分布は水準点に比べ空間的均一性が高いこと から、これまでは認識されていなかった新たな情報をも たらす期待がある. そのような観点から, GPSにより得 られた上下変動速度分布について, 初期的な考察を試み た. その結果, 北海道東部において太平洋プレートが上 盤側プレートと強くカップリングしている領域が， 80 $\mathrm{km}$ 程度のかなり深い領域まで及んでいる可能性がある 
こと, 日高山脈の相対的な隆起は少なくとも interseismic な期間には進行している可能性が高いこと, 中 部山岳地帯が現在は沈降していること, 東海地震の想定 震源域周辺が固着していることなどがわかった。これら のメカニズムを考える上で, 上下変動は有効な情報であ り，それを含んだ総合的な検討によって，テクトニクス に関する議論が深まる期待が高いことが確かめられた。

\section{謝辞}

田部井隆雄博士およびもう1名の匿名査読者による 注意深い査読によって, 本稿は著しく改善された. また, 国土地理院の斎藤 正技官には, 水準測量結果について ご教示いただいた。これらの方々に心からの謝意を表す る. 地図を伴う作図には, Generic Mapping Tool (GMT) [Wessel et al. (1998)]を用いた。

\section{文献}

Ando, M., 1974, Seismo-tectonics of the 1923 Kanto earthquake, J. Phys. Earth, 22, 263-277.

Ando, M., 1975, Source mechanisms and tectonic significance of historical earthquakes along the Nankai trough, Japan, Tectonophysics, 27, 119140.

Aoki, Y. and C. H. Scholz, 2003, Vertical deformation of the Japanese islands, 1996-1999, J. Geophys. Res., 108, B5, 2257, doi: 10.1029/2002JB002129.

壇原 毅, 1971 , 日本における最近 70 年間の総括的上 下変動, 測地学会誌, 17, 3, 100-108.

Ferland, R., 2000, IGS reference frame coodination and working group activities, in "The International GPS Service 2000 Annual Report”, IGS Central Bureau, The Jet Propulsion Laboratory, The California Institute of Technology, 24-27.

Hatanaka, Y., T. Iizuka, M. Sawada, A. Yamagiwa, Y. Kikuta, J. M. Johnson and C. Rocken, 2003, Improvement of the analysis strategy of GEONET, Bull. GSI, 49, 11-35.

Heki, K., S. Miyazaki and H. Tsuji, 1997, Silent fault slip following an interplate thrust earthquake at the Japan trench, Nature, 386, 595-598.

Hugentobier, U., S. Schaer and P. Fredez (eds.), 2001, The BERNESE GPS software version 4.2, Astronomical Institute, University of Bern.

井内 登, 1974, 測地学の概観, 日本測地学会, 119$121,511 \mathrm{pp}$.

Ishibashi, K., 1981, Specification of a soon-to-occur seismic faulting in the Tokai district, central Japan, based upon seismotectonics, in "Earthquake Prediciton-An International Review", Maurice Ewing Series, 4, AGU, Washington D.C., 297-332.

貝塚爽平・鎮西清高 $($ 編 $), 1986$, 日本の山, 日本の自然 2 , 岩波書店, $259 \mathrm{pp}$.

Katsumata, K., N. Wada and M. Kasahara, 2003,
Newly imaged shape of the deep seismic zone within the subducting Pacific plate beneath the Hokkaido corner, Japan-Kuril arc-arc junction, J. Geoophys. Res., 108, B12, 2565, doi: 10.1029/2002 JB002175.

加藤照之・津村建四朗, 1979 , 潮位記録加ら推定される 日本の垂直地殻変動. 地震研究所彙報, 54, 559-628.

環境省, 2003 , 平成 14 年度全国の地盤沈下地域の概況, http://www.env.go.jp/water/jiban/gaikyo/index. html

木村 学, 1981, 千島弧南西端付近のテクトニクス之造 構応力場, 地質学雑誌, 87, 11,757-768.

木村 学, 2002, プレート集束帯のテクトニクス学, 東 京大学出版会, $271 \mathrm{pp}$.

国見利夫・高野良仁・鈴木 実・斎藤 正・成田次範・ 岡村盛司, 2001 , 水隼測量デー夕から求めた日本列島 100 年間の地款上下変動, 国土地理院時報, 96, 2337.

国土地理院，2001，水準測量作業規定，日本測量協会発 行.

国土地理院, 2002, 地震予知連絡会会報, 68, 120-122. 国土地理院, 2003a, 地震予知連絡会会報, 70, 483-489. 国土地理院, 2003b, 新潟地方地盤変動調査測量に関す る報告, 第 55 号, 15 .

国土地理院, 2004, 地震予知連絡会会報, 71, 486 .

Mogi, K., 1970, Recent horizontal deformation of the earth's crust and tectonic activity in Japan (1), Bull. Earthq. Res. Inst., 48, 413-430.

森山昭雄, 1990, 中部山岳地帯における山地形成の時代 性, 米倉伸之・岡田篤正・森山昭雄(編), 变動地形と テクトニクス, 古今書院, 87-109, $254 \mathrm{pp}$.

Munekane, H., M. Tobita and K. Takashima, 2004, Groundwater-induced vertical movements observed in Tsukuba, Japan, Geophys. Res. Lett., 31, L12608, doi: 10.1029/2004GL020158.

Nakayama, F., K. Satake, R. Furukawa, K. Shimokawa, B. F. Atwater, K. Shigeno and S. Yamaki, 2003, Unusually large earthquakes inferred from tsunami deposits along the Kuril trench, Nature, 424, 6949, 660-663.

Nishimura, T., S. Mirura, K. Tachibana, K. Hashimoto, T. Sato, S. Hori, E. Murakami, T. Kono, K. Nida, M. Mishina, T. Hirasawa and S. Miyazaki, 2000, Distribution of seismic coupling on the subducting plate boundary in northeastern Japan inferred from GPS observations, Tectonophysics, 323, 217-238.

Ozawa, S., M. Murakami and T. Tada, 2001, Time dependent inversion study of the slow thrust event in the Nankai trough subduction zone, southwestern Japan, J. Geophys. Res., 106, 787-802.

Ozawa, S., M. Murakami, M. Kaizu, T. Tada, T. Sagiya, Y. Hatanaka, H. Yarai and T. Nishimura, 2002, Detection and monitoring of ongoing aseismic slip in the Tokai Region, Central Japan, Science, 298, 1, 1009-1012.

Ozawa, S., Y. Hatanaka, M. Kaizu, M. Murakami and T. Imakiire, 2004a, Post seismic crustal deforma- 
tion from the $M_{\mathrm{w}} 8$ Tokachi-oki eartqhquake on September 26, 2003 in Japan, Earth Planets Space, 56, 675-680

Ozawa, S., Y. Hatanaka, M. Kaizu, M. Murakami and T. Imakiire, 2004b, Aseismic slip and low frequency earthquakes in the Bungo channel, southwestern Japan, J. Geophys. Res., 31, L07609, doi: 10.1029/2003GL019381.

Sagiya, T., S. Miyazaki and T. Tada, 2000, Continuous GPS array and present-day crustal deformation of Japan, Pure Appl. Geophys., 157, 23032322.

鷺谷 威・井上政明, 2003, アルプスは沈降している か? 一中部日本の上下変動に関する考察一, 日本測 地学会 2003 年秋季大会講演要旨, 69-70.

鷺谷 威・西村卓也・村上 亮・今給黎哲郎 - 赤坂 望, 2003, 地殻活動観測デー夕総合解析システムの開 発, 国土地理院時報, 101, 33-43.

佐藤良輔 - 阿部勝征 - 岡田義光 - 島崎邦彦 - 鈴木保典, 1989, 日本の地震パラメータ・ハンドブック, 鹿島出 版会, $390 \mathrm{pp}$.

Savage, J. C., 1983, A dislocation model of strain accumulation and release at a subduction zone, J. Geophys. Res., 88, 4984-4996.

諏訪謡子 - 三浦 哲 - 長谷川 昭 - 佐藤俊也 - 立花憲
司，2004，東日本沈み込み帯に拈けるプレート境界の 固着状況，地震，2, 56, 471-484.

地震調査研究推進本部, 2003, 千島海溝沿いの地震活動 の長期評価について, http://www.jishin.go.jp/ main/chousa/03mar_chishima/hyoka.pdf

Ueda, H., M. Ohtake and H. Sato, 2003, Postseismic crustal deformation following the 1993 Hokkaido Nanseioki earthquake, northern Japan: Evidence of a low-viscosity zone in the uppermost mantle, J. Geophys. Res., 108, B3, 2150, doi: 10.1029/2001JB 001603.

Wessel, P. and W. H. F. Smith, 1998, New improved version of generic mapping tools released, EOS Trans. Am. Geophys. Union, 79, 47, 579.

Yabuki, T. and M. Matsu'ura, 1992, Geodetic data inversion using a Bayesian information criterion for spatial distribution of fault slip, Geophys. J. Int., 109, 363-375.

吉岡祥一, 1999, 1944 年東南海, 1946 年南海地震に伴 う変位・歪み・応力場の数值シミュレーション, 1999 地球惑星科学関連学会合同大会予稿集, DG017.

吉山 昭・柳田 誠, 1995 , 河成地形面の比高分布から みた地殻変動, 地学雑誌, 104, 6, 809-826. 